\title{
A UT/LS ozone climatology of the nineteen seventies deduced from the GASP aircraft measurement program
}

\author{
C. Schnadt Poberaj ${ }^{1}$, J. Staehelin ${ }^{1}$, D. Brunner ${ }^{2}$, V. Thouret ${ }^{3}$, and V. Mohnen ${ }^{4}$ \\ ${ }^{1}$ Institute for Atmospheric and Climate Science, ETH Zürich, Switzerland \\ ${ }^{2}$ Laboratory for Air Pollution/Environmental Technology, Empa, Dübendorf, Switzerland \\ ${ }^{3}$ Laboratoire d'Aérologie, UMR 5560, Université Paul Sabatier, Toulouse, France \\ ${ }^{4}$ Atmospheric Sciences Research Center, State University of New York at Albany, Albany, New York, USA
}

Received: 17 January 2007 - Published in Atmos. Chem. Phys. Discuss.: 6 March 2007

Revised: 9 July 2007 - Accepted: 19 November 2007 - Published: 29 November 2007

\begin{abstract}
We present ozone measurements of the Global Atmospheric Sampling Program (GASP) performed from four commercial and one research aircraft in the late 1970s. The GASP quality assurance and control program was reviewed, and an ozone climatology of the upper troposphere and lower stratosphere (UT/LS) of the years 1975-1979 was built. The data set was estimated to have an overall uncertainty of $9 \%$ or $3 \mathrm{ppb}$ whichever is greater for the first two years and $4 \%$ or $3 \mathrm{ppb}$ for the remaining years, i.e. after implementation of silicone rubber membranes in the pumps. Two cases of nearly coincident flights of two GASP airliners along the same flight route, and the comparison with independent observations from the literature, including ozonesondes and aircraft campaigns, indicate that the ozone measurements are of high quality. The UT/LS climatology of the GASP data set is in general agreement with that derived from MOZAIC in the 1990s in regions covered by both programmes. GASP provides unique large-scale climatological information on UT/LS ozone above the northern hemisphere Pacific region, which is not covered by MOZAIC. There, the GASP climatology confirms several characteristic features derived from individual research aircraft campaigns and from ozone soundings. In particular, summertime ozone in the UT over the midlatitude eastern Pacific Ocean was significantly lower in the 1970s than over the American continent. The generally lower ozone concentrations in the tropics near the dateline as compared to farther east are indicative of convective uplifting of ozone poor air from the marine boundary layer.
\end{abstract}

Correspondence to: C. Schnadt Poberaj

(christina.schnadt@env.ethz.ch)

\section{Introduction}

Ozone is one of the key trace constituents in the atmosphere. It absorbs solar ultraviolet (UV) radiation in the stratosphere protecting the Earth's surface from UV-B and UV-C radiation. In the troposphere, its photolysis leads to the production of the hydroxyl radical $(\mathrm{OH})$, the most important oxidant of tropospheric chemistry. In addition, ozone absorbs infrared radiation making it an important greenhouse gas. Changes in stratospheric, UT/LS, and tropospheric ozone thus alter the radiative balance of the atmosphere leading to changes in surface temperature. Applying the same percentage ozone increase to different altitudes in a radiativeconvective model, Forster and Shine (1997) showed that both lower stratospheric and tropospheric ozone changes significantly contribute to changes in surface temperature, the maximum contribution, however, is obtained for an ozone increase applied in the tropopause region. In recent years much attention has therefore been laid on a better understanding of UT/LS ozone and the chemical and dynamical processes that govern its concentration (WMO, 1998; IPCC, 2001).

Information on stratospheric ozone and its changes over time can be inferred from ground-based total ozone measurements (e.g., WMO, 1999, 2007; Staehelin et al., 2001), and since 1978, additional information has been available from quasi-global and almost continuous satellite measurements providing information on total ozone and the stratospheric profile. In addition, measurements from regular ozonesondes have been recording profile information of the troposphere and the stratosphere below $30 \mathrm{~km}$ since the late 1960s (e.g., Logan, 1985, 1999). Early ozonesonde profiles, however, were recorded at only few stations in Europe, Canada, and Japan, and the data quality of the tropospheric part of these

Published by Copernicus Publications on behalf of the European Geosciences Union. 
profiles is difficult to assess (WMO, 1998). This is especially true for the 1960s and 1970s, where no comparative measurements have been available so far (Logan et al., 1999). Much better spatial data coverage is available at cruising altitudes in the UT/LS through the Measurement of Ozone and Water Vapor by Airbus in Service Aircraft Program (MOZAIC) (Marenco et al., 1998.; Thouret et al., 1998a; Thouret et al., 2006) since 1994. As a result of the sparsity of measurements before the 1990s, long-term changes of UT/LS ozone are difficult to assess for large parts of the globe.

In this study, we present an ozone data set collected by the Global Atmospheric Sampling Program (GASP) in the late 1970s (Falconer and Holdeman, 1976; Nastrom, 1977, 1979) which provides an unprecedented possibility to obtain information on the large-scale climatological ozone distribution in the UT/LS during that period. Ozone measurements from the GASP project were carried out on flights of four commercial B-747 airliners and one research aircraft during the period 1975 to 1979 . Ozone data were gathered over large parts of the subtropical and midlatitude northern hemisphere (NH) focusing on North America, the Pacific, and the Atlantic regions, but also including some measurements over Europe, South and East Asia, and Australia. It should be especially emphasised that GASP provides large-scale coverage above the Pacific Ocean, a region for which a representative data set has been missing so far.

This paper is intended to revisit an important and hitherto under-utilized data set established in the 1970s. The paper first describes the GASP measurement system and investigates some aspects of data quality, which will be important for future applications of the data. The paper then focuses on the climatology of UT/LS ozone established from the measurements. In addition, it includes a comparison with MOZAIC measurements to demonstrate the close resemblance of the two data sets in terms of vertical profiles, seasonal cycles and absolute abundances. In a forthcoming companion paper, long-term changes between the late nineteen seventies and nineteen nineties deduced from the GASP and MOZAIC data sets will be presented and discussed in comparison with respective changes obtained from ozonesonde measurements.

In Sect. 2, the data sets used are described, including a comprehensive survey of the GASP instrumentation, as well as of the quality assurance and control procedures management. Section 3 presents the applied method of data analysis. In Sect. 4, the GASP ozone climatology is discussed including vertical profiles (Sect. 4.1), seasonality of upper tropospheric ozone in specific regions of the northern hemisphere (Sect. 4.2), and a specific climatology over the Pacific (Sect. 4.3). Finally, Sect. 5 contains the summary and conclusions.

\section{Data}

\subsection{The Global Atmospheric Sampling Program (GASP)}

From 1975 to 1979, the National Aeronautics and Space Administration (NASA) conducted the Global Atmospheric Sampling Program (GASP). The aim was "to measure the temporal and spatial distribution of particulate and gaseous constituents related to aircraft engine emissions in the upper troposphere and lower stratosphere" (Perkins and Reck, 1973). While a large number of NASA reports document the GASP program and present some aspects of UT/LS ozone (e.g., Falconer et al., 1978, 1983; Gauntner et al., 1977; Falconer and Pratt, 1979; Holdeman and Nastrom, 1981b; available at http://ntrs.nasa.gov/search.jsp), only few results were published in refereed scientific journals (Falconer and Holdeman, 1976; Nastrom, 1977, 1979) and none of these provided a comprehensive climatology of ozone.

Four in-service B-747 of United Airlines (1), Pan Am (2) and Qantas (1), as well as the NASA CV-990 research aircraft were equipped with identical automated instrument platforms to measure ozone, aerosols, condensation nuclei, water vapour, and carbon monoxide. Whereas the quality of the condensation nuclei measurements was assessed to be questionable and the carbon monoxide data overlaid with instrument noise (Wozniak, 1997), GASP ozone was considered more reliable in the same study. For this reason, we focus on the ozone measurements and will, in the following sections, show that the data are indeed of high quality.

Data are available from March 1975 to June 1979 when the funding for the program was cut. Altogether, the GASP period contains 6149 measurement flights. The overwhelming part of data were collected by the two Pan Am N655PA and N533PA (28\% and 34\%, respectively), the UAL (24\%), and the QANTAS aircraft (14\%). Only a minor contribution of data stems from the NASA CV-990 aircraft $(0.2 \%)$. The latter data were gathered on 11 measurement flights across the Pacific and south of Australia as part of the Latitude Survey Mission in November 1976, which aimed at detecting ozone in the stratosphere radiometrically (Lange et al., 1981, see http://ntrs.nasa.gov/archive/nasa/casi.ntrs.nasa. gov/19810020074_1981020074.pdf). As the aim of the program was to monitor the UT/LS region, measurements were carried out in the middle and upper troposphere and the lower stratosphere at altitudes between 6 and $13.7 \mathrm{~km}$. The program mostly covered the North Atlantic and Pacific Oceans, as well as the North American continent, but also to a lesser extent Europe (Fig. 1a). A smaller number of flights went to destinations in India, Singapore, Australia, New Zealand, and also to Rio de Janeiro and Sao Paulo in South America. The altitude range of GASP measurements is given in Table 1: most of the data were sampled at the standard flight levels $196 \mathrm{hPa}(15.9 \%), 216 \mathrm{hPa}(20.9 \%)$, and $238 \mathrm{hPa}$ $(19.3 \%)$. For comparison, Fig. 1b shows the coverage of flights from the MOZAIC program (note the different colour 

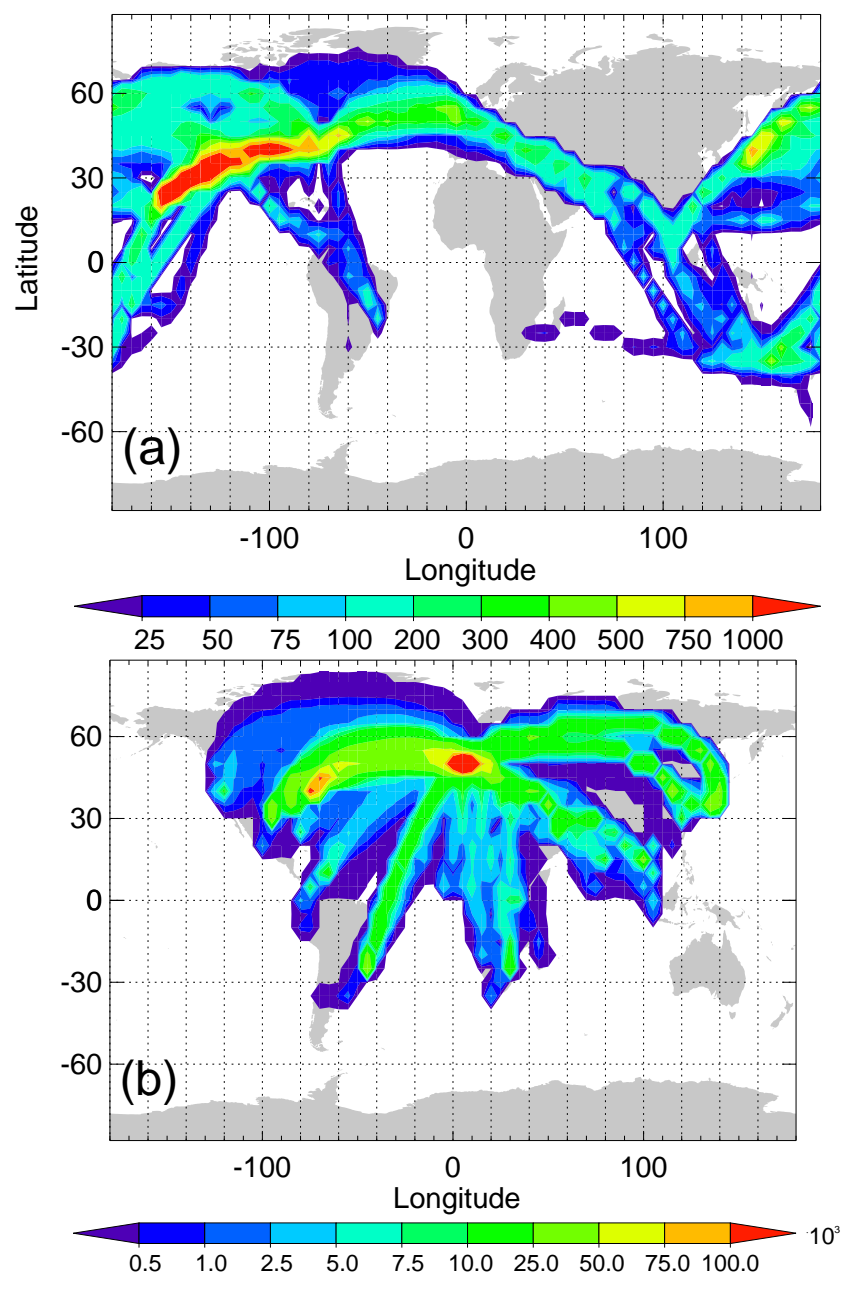

Fig. 1. Number of measurements and distribution of flight routes for the (a) GASP and (b) MOZAIC aircraft programs. Measurements counted over a $5^{\circ} \times 5^{\circ}$ grid during (a) 1975-1979 and (b) 19942001. Note the different colour scales for GASP and MOZAIC flight routes. MOZAIC colour scale needs to be multiplied by 1000 to obtain number of measurements.

scaling) based from Europe, but with large areas of spatial overlap with GASP.

\subsubsection{The GASP system and ozone monitor}

The sample-collecting system consisted of two air-sampling inlets in a single strut mounted outside the aircraft near the nose. One inlet was designed for near-isokinetic sampling used for particle measurements, the other inlet served to measure trace gases. Below $6 \mathrm{~km}$ altitude both inlets were closed and the system switched to standby mode to prevent contamination with polluted air at the ground and in the airport environment. To achieve the desired measurement sensitivity and to minimize leakage of cabin air into the system, the air sample from the second inlet was pressurized by means of a di-
Table 1. Characteristics of flight levels for GASP and MOZAIC data. Altitude ranges $(\mathrm{hPa})$ represent predominant flight altitudes. Standard altitudes $(\mathrm{km} / \mathrm{kft})(\mathrm{kft}=1000 \mathrm{feet})$ derived from standard pressure levels using the ICAO standard atmosphere.

\begin{tabular}{cccccc}
\hline $\begin{array}{c}\text { \% of Data: } \\
\text { GASP }\end{array}$ & $\begin{array}{c}\text { \% of Data: } \\
\text { MOZAIC }\end{array}$ & $\begin{array}{c}\text { Altitude range } \\
\text { (hPa) }\end{array}$ & \multicolumn{3}{c}{ Standard level } \\
& & & $\mathrm{hPa}$ & $\mathrm{km}$ & $\mathrm{kft}$ \\
\hline 4.2 & 2.8 & $288-286$ & 287 & 9.5 & 31 \\
10.5 & 12.1 & $263-259$ & 262 & 10.1 & 33 \\
1.3 & 2.0 & $250-249$ & 250 & 10.4 & 34 \\
19.3 & 20.8 & $242-236$ & 238 & 10.7 & 35 \\
4.2 & 4.3 & $228-226$ & 227 & 10.9 & 36 \\
0.1 & 4.3 & $223-221$ & 222 & 11.1 & 36 \\
20.9 & 13.7 & $218-215$ & 216 & 11.3 & 37 \\
1.1 & 4.1 & $207-204$ & 206 & 11.6 & 38 \\
15.9 & 8.5 & $198-195$ & 196 & 11.9 & 39 \\
7.3 & - & $180-178$ & 179 & 12.5 & 41 \\
1.8 & - & $163-161$ & 162 & 13.1 & 43 \\
\hline
\end{tabular}

aphragm pump to a constant pressure of $0.99 \pm 0.02 \mathrm{~atm}$, well above cabin pressure. In order to minimize ozone destruction in the sample flow system, all lines were made of Teflon and the pump diaphragm was covered with a Teflon-impregnated fibreglass cloth material. The absorption chamber was a folded-tube arrangement with an effective length of $71 \mathrm{~cm}$. The tubes were aluminium internally coated with Kynar, and had quartz windows and mirrors. Here, the main features of the GASP ozone instrument, the operation and quality assurance and control procedures will be summarised (for more details see Tiefermann, 1979; PDF available at NASA Technical Reports Server, http://ntrs.nasa.gov/search.jsp). The instrument was a commercially available UV photometer manufactured by Dasibi Environmental Corporation, which measured in the range of 3 to $1000 \mathrm{ppbv}$. To meet airline safety standards and environmental requirements and to allow automated operation, the instrument was specially modified by Dasibi. The measurement principle was based on the absorption of UV light by ozone, a technique which is still standard in today's ozone monitors and which was also used in the MOZAIC and NOXAR aircraft measurement programs (Thouret et al., 1998b; Dias-Lalcaca et al., 1998; Klausen et al., 2003). Ozone concentrations were derived by alternately exposing sample gas and ozone-free zero gas in the absorption chamber to an ultraviolet beam from a low-pressure mercury lamp at $253.7 \mathrm{~nm}$ and determining the difference in intensity. Note that the value for the absorption coefficient utilised in the GASP program $\left(308.5 \mathrm{~cm}^{-1} \mathrm{~atm}^{-1}\right)$ is the standard value according to Hearn (1961), which is still used today including the MOZAIC program (personal communication, P. Nédélec). 


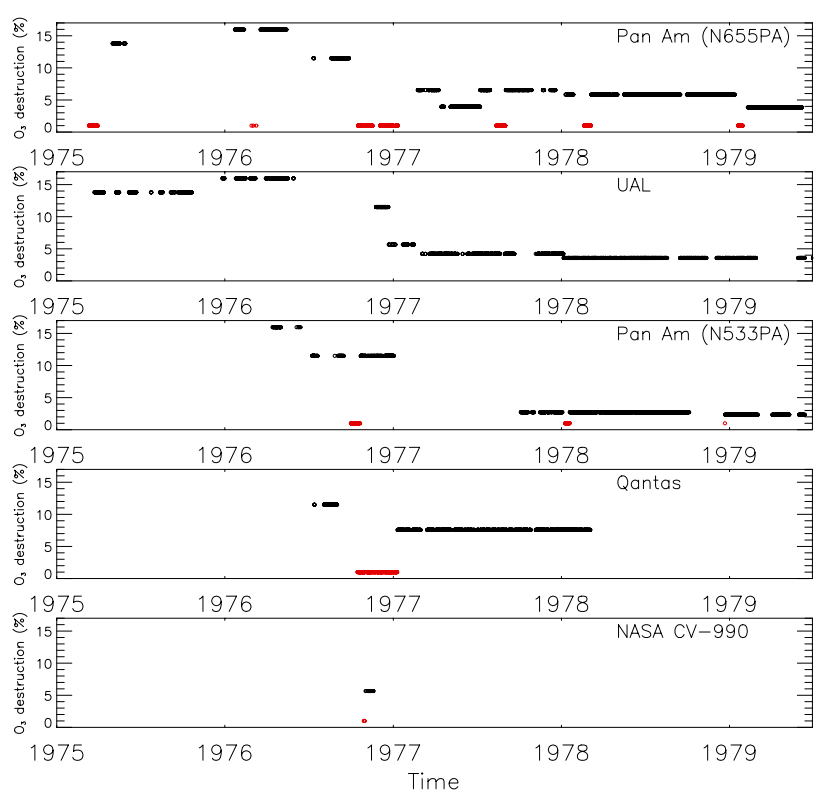

Fig. 2. Ozone destruction rates (\%) between the probe inlet and the ozone monitor as function of time and aircraft. From top to bottom: Pan Am (N655PA), United Airlines (UAL), Pan Am (N533PA), Qantas, NASA CV-990. Red dots at 1\% ozone destruction denote times, when aircraft were flying, but ozone destruction rates were not recorded.

A basic 60-min sampling cycle of the GASP system was constructed by alternating 5-min air-sampling periods and 5min instrument control periods yielding six measurements per hour and six instrument control mode outputs taken each cycle. Due to limitations in data storage capacity, the data were only recorded during a 20-s interval at the end of each five minute air-sampling or control period and averaged over the last $5 \mathrm{~s}$ (see below). For the ozone instrument, two of the control periods were additionally used for air-sampling such that eight data records were taken per hour. Assuming the speed of a Boeing 747 to be about $900 \mathrm{~km} / \mathrm{h}$ at cruise altitudes, this results in in-situ observations made at approximately every $110 \mathrm{~km}$.

The 20-s measurement intervals were composed of a $10 \mathrm{~s}$ sample cycle and a $10 \mathrm{~s}$ zero-gas cycle during which the sample gas was directed through an ozone scrubber that destroyed all ozone and generated a zero gas. The first $5 \mathrm{~s}$ of each cycle were used for flushing and the last $5 \mathrm{~s}$ for measuring.

2.1.2 Quality assurance and quality control (QA/QC) procedures

A total of 10 identical ozone monitors were available for installation on the airliners. Operation of the instruments during the four year period included a comprehensive QA/QC program described in the internal Quality Assurance Plan and associated documents. An equipment log was kept on each monitor where the date and results of all calibrations, repairs, adjustments and routine functional tests were recorded. Ozone monitors were frequently (about two to four times per year) exchanged for calibration and functional tests in the laboratory. Ozone scrubbers were exchanged every three months to prevent their degradation with time which would be difficult to detect during flight. Hourly in-flight checks included a test of the instruments zero during which the sample was directed through the scrubber in the same way as during a zero-gas cycle. Monitoring the zero-gas output with time provided an indication of the instruments' stability. Hourly readouts of the sample pulse rate (proportional to the light intensity at the detector) allowed detecting a possible degradation of the mercury lamp or the presence of contaminants in the absorption tube. Instruments were replaced when sample pulse rates dropped below a critical value (accepted range was $250-480 \mathrm{kHz}$ ).

Probably the most critical problem of the GASP system, however, is that some ozone was destroyed upstream the ozone monitor, mostly caused by temperature rise of the sample gas in the pump, but also by contamination in the sample flow line and in the pump. As the amount of destruction varied between pumps and with operation time, an ozone-destruction test package, developed at the NASA Lewis Research Center in Cleveland, Ohio, was used to measure the destruction during regular checks. The evolution of ozone destruction with time determined for the five aircraft is shown in Fig. 2. Destruction rates were as high as $16 \%$ in 1975 and 1976, with a random error in determining the amount of destruction as high as $\pm 8 \%$. The amount of destruction was reduced in 1977 to less than 6\% (and the associated error to $\pm 2 \%$ ) when the Buna-N rubber diaphragms were changed to silicone rubber. This lower fraction of ozone loss in the inlet lines and pump is comparable to that reported for the NOXAR system (Dias-Lalcaca et al., 1998). Ozone destruction tests were carried out periodically and the ozone values corrected accordingly. Figure 2 also shows that for all aircraft, but the United Airlines airplane, there are periods where the coefficient for ozone loss reported in the data files was set to zero. This was caused by less diligent recording by Pan Am and Qantas, but does not affect the reported ozone values which were corrected for losses also in these cases assuming constant destruction rates before and after the gaps.

Before installation into GASP systems, each ozone monitor was calibrated against a Dasibi transfer standard (model 1003-AH). Stability of the instruments' sensitivity was generally excellent and over the course of a year changed by less than 1 percent (Fig. 3). Until February 1977, the transfer standard itself was calibrated by using the 1-percent-neutralbuffered-potassium-iodide (KI) method. Because the accuracy and reproducibility of this method had been questioned, the transfer standard was then calibrated at the Jet Propulsion Laboratory (JPL) against a UV photometry standard. There, it was found that the GASP data had a $9 \% \pm 2 \%$ high bias relative to the JPL standard (Tiefermann, 1979). Accord- 
ing to Tiefermann, the archived data were not corrected for this discrepancy. The overall uncertainty (total error) of any ozone measurement was presented in Tiefermann (1979) as the root-sum square

$$
E_{\text {total }}=\sqrt{E_{S}^{2}+E_{g}^{2}+E_{t / p}^{2}+E_{d}^{2}+E_{r}^{2}}
$$

where $E_{s}$ is the error in the JPL calibration of the GASP transfer standard $( \pm 2 \%), E_{g}$ the error in the calibration of each monitor against the GASP transfer standard $( \pm 1 \%)$, $E_{t / p}$ the error in measuring the sample gas temperaturepressure ratio $( \pm 1 \%), E_{d}$ the error in determining the ozone destruction constant $( \pm 8 \%$ for rubber and $\pm 2 \%$ for silicone), and $E_{r}$ the instrumental precision or random error of a single ozone instrument reading, which is $\pm 1 \%$ or 3 ppbv, whichever is greater.

For any reading between 300 and $1200 \mathrm{ppbv}$, the overall uncertainty was hence estimated to $\pm 8.4 \%$ (1975/76) or $\pm 3.3 \%$ (from 1977 onward) depending on the error $E_{d}$ in determining the ozone destruction constant (see above and Fig. 2). For very low ozone concentrations, the overall uncertainty approaches 3 ppbv.

\subsubsection{Pre-processing of the GASP data set}

Before using the GASP ozone data for building the climatology, a thorough check for data consistency and quality was carried out. Three major issues were found which were necessary to be treated before using the data:

- The high bias of $9 \%$ described above was corrected for (cf. previous section).

- Although the ozone data were supposed to have a temporal resolution of five to ten minutes (cf. Sect. 2.1.1), sometimes up to 16 samples per minute were recorded. These high temporal resolution data were encountered frequently during all five GASP years and for all aircraft. Indeed, there are specific months, i.e. October 1977 and October 1978 through March 1979, where a large part of the data was stored at high time resolution. October 1977 refers to the month where four acrosspole flights of the N533PA Pan Am aircraft were undertaken within the scope of the Pan Am Fiftieth Anniversary (Holdeman et al., 1978). The high temporal resolution data were recorded on purpose to document these special flights. The increased time resolution between October 1978 and March 1979 was introduced in conjunction with an activity to measure passenger exposure to cabin air ozone in commercial airliners (Holdeman and Nastrom, 1981a). Although the high temporal resolution flights would be interesting to investigate, e.g. for case studies, using them in a climatological averaging process, however, would lead to false results. Thus, for the purpose of this study, one minute averages were computed for those times where a specific aircraft had

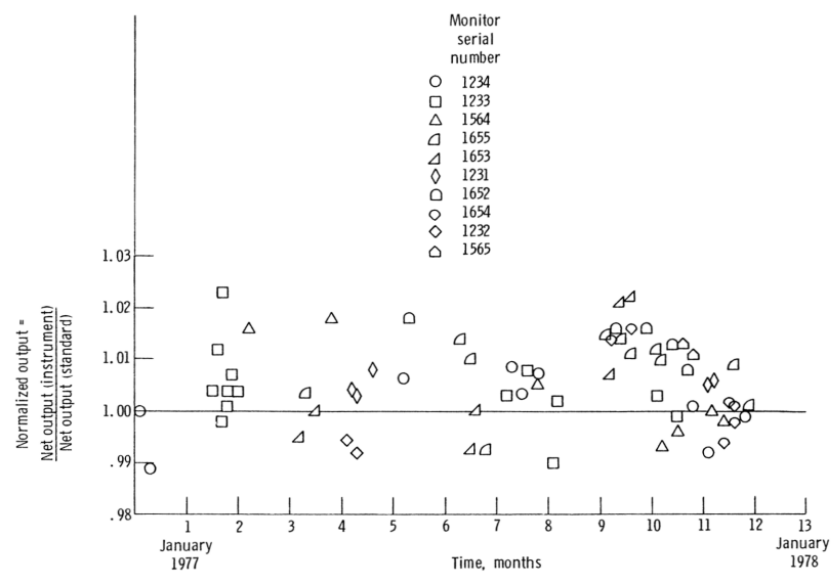

Fig. 3. Individual GASP ozone monitor calibrations against the Dasibi transfer standard instrument. Mean 1.005, standard deviation 0.8\%. From Tiefermann (1979).

more than one measurement recorded in a minute. Subsequently, the final data record was built by considering only a single one-minute average out of five within any given five minute period for consistency with the normal operating procedure. As a result of this procedure, the amount of data was reduced by $53 \%$.

- As already noted by Wozniak (1997), there were obviously some erroneous readings within the large number of measurements that were not flagged in the routine data archival procedure (flagged data were not included in the analysis). This resulted in spuriously low ozone values on the order of some ppbv in the UT and values less than some tens of ppbv in the LS occurring at all latitudes and seasons. We acknowledge that this may constitute a real problem of the data set especially in the tropics where some fraction of these low mixing ratios may indeed have occurred as a result of convection (Kley et al., 1997). However, since the spurious values do not occur systematically in the records, they could not be distinguished from true very low data. For this reason, using ozone probability density functions (not shown), suspicious data with $\mathrm{O}_{3}<10 \mathrm{ppbv}$ in the UT and with $\mathrm{O}_{3}<30 \mathrm{ppbv}$ in the LS were identified and removed prior to analysis. As consequence, another $8.4 \%$ of the five-minute data were considered not reliable and eliminated from the data set.

Considering all above issues and two additional minor reductions described in Sect. 3, the original data set, which contained 278642 measurements, was reduced by $58 \%$ altogether, leaving little more than 117000 records covering little less than 14200 flight hours. 


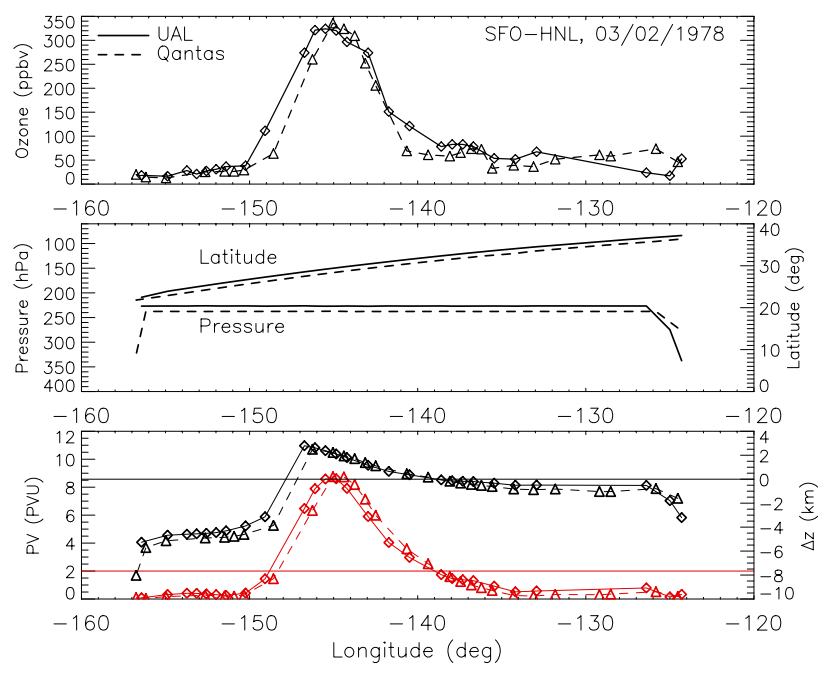

Fig. 4. Comparison of the measurements from the United Airlines (UAL) B-747 and the Qantas B-747 on near "simultaneous" flights on 02 Feb, 1978, from San Francisco (SFO) to Honolulu, Hawaii (HNL). Time difference between flights approximately one hour. Solid lines (with diamonds in top and bottom row): UAL, dashed lines: Qantas (with triangles in top and bottom row). Upper row: ozone (ppbv), middle row: pressure (hPa) and latitude (degrees), bottom row: PV (PVU) (red curves) and distance from the $2 \mathrm{PVU}$ tropopause $(\mathrm{km})$.

\subsubsection{Internal consistency of GASP ozone measurements}

Besides the quality assurance and control procedures described in Sect. 2.1.2, independent quantitative information on the accuracy and precision of the measurements can be gained from a few occasions where two different GASP aircraft were flying close in time and space. Two near "simultaneous" flight situations were identified in the record. On 03/02/1978, the two GASP airplanes of United Airlines (UAL) and Qantas went from San Francisco (airport acronym: SFO) to Honolulu, Hawaii (HNL) at a time difference of little more than one hour. On 22/06/1978, the Pan Am (N655PA) and the UAL aircraft went from Los Angeles (LAX) to Honolulu at 31-36 min distance. Figures 4 and 5 depict the main characteristics of these flights as function of longitude. On both days, ozone measurements by the different aircraft agree very well in qualitative terms as long as cruise altitudes are similar. To quantitatively assess agreement between measurements, correlations and linear fits were calculated by matching the closest horizontal data points under the constraint that cruise altitudes should not differ by more than one flight level. This limits the data chosen to longitudes less than $126^{\circ} \mathrm{W}$ for the flights on $03 / 02 / 1978$ and to less than $146^{\circ} \mathrm{W}$ for the flights on 22/06/1978 (Figs. 4 and 5, second row from top). Correlation coefficients amount to 0.97 and 0.67 for the flights on $03 / 02 / 1978$ and $22 / 06 / 1978$, respectively. The correla-

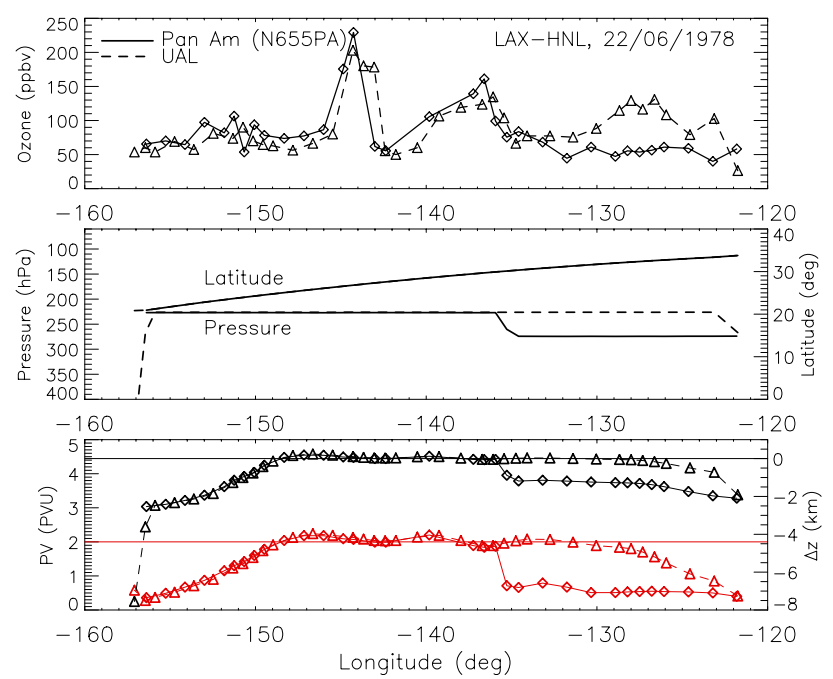

Fig. 5. As in Fig. 4, but comparison between the United Airlines (UAL) B-747 and the Pan Am (N655PA) B-747 on 22 Jun, 1978, from Los Angeles (LAX) to Honolulu, Hawaii (HNL). Time difference between flights half an hour.

tion coefficient on 22/06/1978 can be improved to 0.94 when shifting the first flight by Pan Am $0.3^{\circ}$ to $0.8^{\circ}$ to the east. The improved correlation can be explained by eastward advection of the air mass through high wind speeds of 30 to $35 \mathrm{~m} / \mathrm{s}$ in approximately westerly flow prevailing between $145^{\circ} \mathrm{W}$ and Honolulu (not shown): At a westerly wind of $30-35 \mathrm{~m} / \mathrm{s}$, an air parcel will be displaced to the east by $56-76 \mathrm{~km}$ in $31-$ $36 \mathrm{~min}$. This corresponds to a longitudinal shift of $0.5^{\circ}$ to $0.8^{\circ}$ at $20^{\circ} \mathrm{N}-30^{\circ} \mathrm{N}$ approximately fitting the applied shift to the data. The linear fits are

$\left[\mathrm{UAL}-\mathrm{O}_{3}\right]=15.6 \mathrm{ppbv}( \pm 8.0 \mathrm{ppbv})+0.969( \pm 0.057) \cdot\left[\mathrm{QANTAS}-\mathrm{O}_{3}\right]$

$\left[\mathrm{UAL}-\mathrm{O}_{3}\right]=2.1 \mathrm{ppbv}( \pm 8.5 \mathrm{ppbv})+0.873( \pm 0.079) \cdot\left[\mathrm{PANAM}-\mathrm{O}_{3}\right]$

with the values in brackets denoting the 1-sigma uncertainty of the regression coefficients. On 03/02/1978, the mean deviation is almost $16 \mathrm{ppbv}$ (Eq. 2), which can probably be explained by slight differences in flight latitude and altitude (Fig. 4, middle row) with the UAL aircraft flying one flight level higher than Qantas. Due to close proximity to the local tropopause during the first half of the distance and encountering of stratospheric air thereafter (Fig. 4, bottom row), even minor vertical displacement can result in different ozone concentrations (cf. also Sect. 4.1, Fig. 6). Much better agreement in terms of intercept is found for the comparison of the UAL and the Pan Am (N655PA) aircraft on 22/06/1978 (Eq. 3), where differences are close to the stated uncertainty despite 
Table 2. Main characteristics of the GASP program and ozone monitor. (*) Note that in the original paper by Tiefermann (1979) the uncertainties were rounded to the next lower values ( $8 \%$ and $3 \%$ ), while we have chosen to round them up.

\begin{tabular}{ll}
\hline & GASP \\
\hline Aircraft & Four commercial B-747, NASA CV-990 research aircraft \\
Species & $\mathrm{O}_{3}, \mathrm{H}_{2} \mathrm{O}, \mathrm{CO}, \mathrm{NO}$, aerosols, CCN \\
Altitude range & $6-13.7 \mathrm{~km}$ \\
Number of flights & 6149 \\
Ozone instrument & UV photometer (manufactured by Dasibi Environmental Corporation) \\
Measurement range & $3-1000 \mathrm{ppbv}$ \\
Instrumental precision $\left(E_{r}\right)$ & $\pm 1 \%$ or 3 ppbv, whichever is greater \\
Overall uncertainty $\left(E_{\text {total }}\right)$ & $9 \%(1975 / 76)$ or 4\% (from 1977 onward) depending on diaphragm \\
& material $(*)$. For very low ozone concentrations: $E_{\text {total }} \rightarrow 3$ ppbv \\
Temporal resolution & $5 \mathrm{~s}$ averages every $5-10$ min \\
\hline
\end{tabular}

additional uncertainty introduced by meteorological variability. However, as result of the relatively small sample size (19 data pairs, out of which 6 are from the lower stratosphere), the regression is significantly influenced by individual data pairs in the lower stratosphere resulting in a slope that is a little smaller than one. No sufficient match in time and space with one of the other aircraft was found for the second Pan Am (N533PA). However, due to the frequent exchange and cycling of ozone monitors and the virtually identical GASP installations, there is no reason to suspect the measurements of this aircraft to be of different quality.

The main characteristics of the GASP system and ozone monitor have been summarised in Table 2 .

2.2 The Measurement of Ozone and Water Vapor by Airbus in Service Aircraft Program (MOZAIC)

Data from the Measurement of Ozone and Water Vapor by Airbus in Service Aircraft Program (MOZAIC) are used for comparison with the GASP measurements in Sects. 4.1 and 4.2. MOZAIC started measurements in August 1994. Detailed descriptions of the program and first results can be found in a special issue of the Journal of Geophysical Research from 1998 (Marenco et al., 1998; Thouret et al., 1998a, b). Five Airbus of Air France, Sabena, Lufthansa (2), and Austrian Airlines have been equipped with fully automated instruments to measure ozone and water vapour during in-service flights. MOZAIC flight routes can be inferred from Fig. 1b. Note that unlike in the GASP campaign, MOZAIC aircraft measurements so far do not cover the Pacific Ocean region.

The ozone analyser is a dual beam UV absorption instrument (Thermo-Electron, model 49-103) with an absolute accuracy of $1 \%$ and instrument precision of 2 ppbv. The characteristics of ozone measurements on board the MOZAIC aircraft are a detection limit of $2 \mathrm{ppbv}$ and uncertainties for individual measurements of $\pm[2 \mathrm{ppbv}+2 \%]$. Accuracy and precision of the MOZAIC instruments were constant during the whole 1994-2001 period. Further information on the quality control and calibration procedures can be obtained from Thouret et al. (1998b). Measurements are taken every 4 seconds, starting after takeoff and continuing to landing. However, most data have been collected at cruise levels between 9 and $12 \mathrm{~km}$ (Table 1). The MOZAIC instrument is similar to the GASP instrument in many respects, including the basic measurements principle of absorption of UV light at $253.7 \mathrm{~nm}$ from a Mercury lamp, the use of a scrubber to generate zero air, and the pre-compression of the sample air using a diaphragm pump. In this study, the pre-processed one minute average data are used for the period of August 1994 through December 2001. Horizontally, the one minute averages result in a record being representative of approximately $15 \mathrm{~km}$ flight path (assuming an average air speed of $900 \mathrm{~km} / \mathrm{h}$ ). Between August 1994 and December 2001, 14558 MOZAIC flights were carried out that consisted of 113008 flight hours altogether. The chosen period ending in December 2001 results from the availability of ECMWF 40-year reanalyses used in this study (cf. next section).

For consistency, the MOZAIC data were pre-processed in an analogous way as the GASP data eliminating all ozone readings below $10 \mathrm{ppbv}$ in the UT and below $30 \mathrm{ppbv}$ in the LS (cf. Sect. 2.1.3). The processing resulted in a minor reduction of the data set of $1.9 \%$.

\section{Method of data analysis}

The GASP aircraft data mostly cover the region of the upper troposphere, the tropopause region, and the lowermost stratosphere. Whereas tropospheric ozone concentrations are relatively constant over altitude, they strongly increase in the lower stratosphere and are, thus, highly dependent on position with respect to the tropopause (e.g., Logan, 1999).

For this reason, the GASP and MOZAIC aircraft data were arranged relative to the tropopause. To discriminate between tropospheric and stratospheric air masses, the $2 \mathrm{PVU}$ 

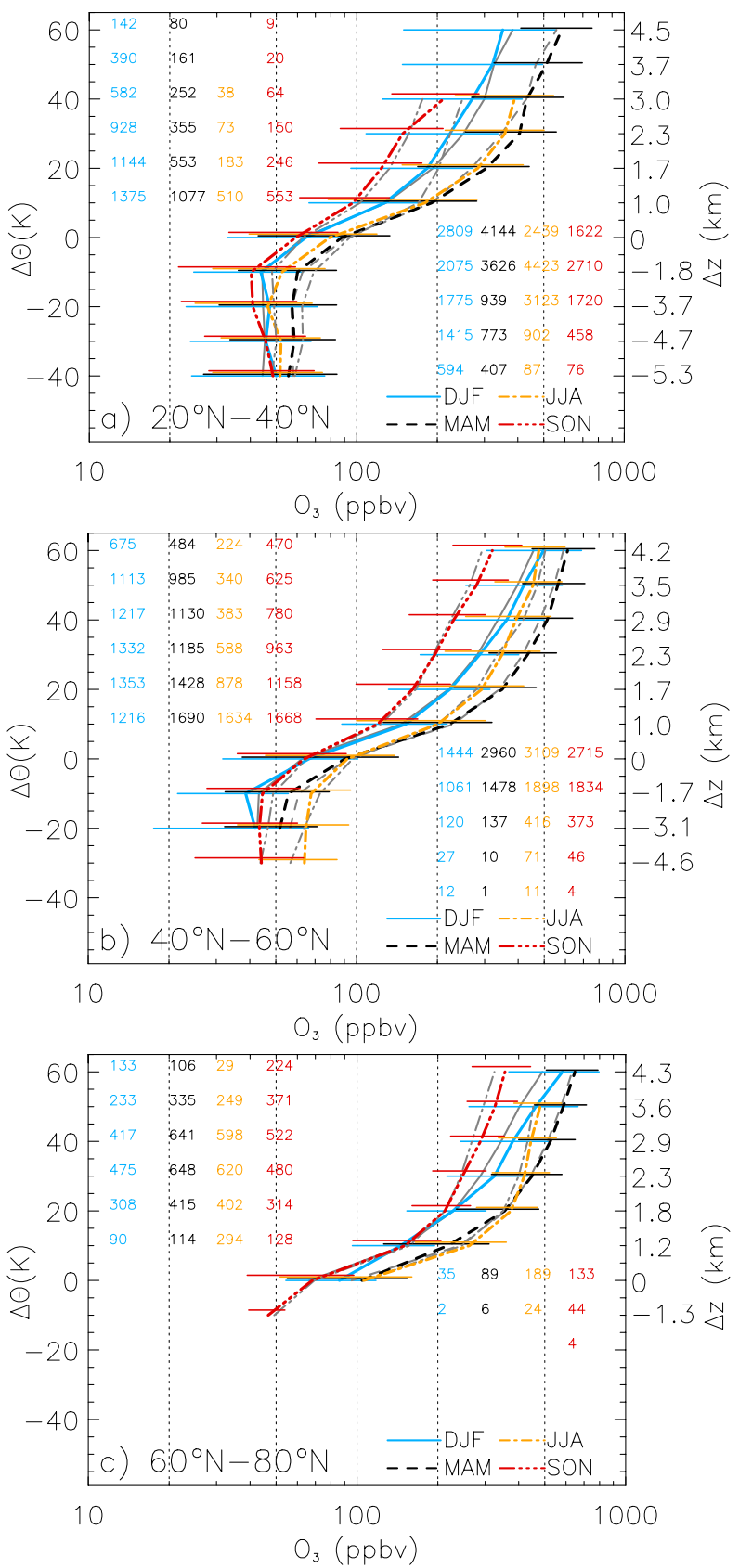

Fig. 6. Climatological mean ozone profiles for the GASP period 1975-1979 as function of potential temperature distance to the dynamical tropopause and season (DJF blue solid line, MAM black dashed line, JJA orange dashed-dotted line, SON red dashed-dotdotted line). (a) $20^{\circ} \mathrm{N}-40^{\circ} \mathrm{N}$, (b) $40^{\circ} \mathrm{N}-60^{\circ} \mathrm{N}$, and (c) $60^{\circ} \mathrm{N}-$ $80^{\circ} \mathrm{N}$. Stratospheric profiles $(\Delta \theta>0 \mathrm{~K})$ are filtered for equivalent latitudes for (b) and (c). Tropospheric $(\Delta \theta<0 \mathrm{~K})$ and tropical stratospheric profiles are selected for geographical latitudes. Horizontal bars indicate one standard deviation. Number of records per $10 \mathrm{~K}$ bin of $\Delta \theta$ and per season are given in the right (left) part of the graphs in the UT (LS) (from left to right: DJF, MAM, JJA, SON). For comparison, MOZAIC 1994-2001 climatological profiles are indicated as grey lines in analogous style as GASP profiles. dynamical tropopause was used, because it best coincides with the ozonopause (Zahn et al., 1999). Besides PV, tropopause pressure, and potential temperature at the dynamical tropopause, temperature and potential temperature at cruise altitude were interpolated temporally and spatially from the 40 year ECMWF reanalyses data set (ERA40, Uppala et al., 2005) onto the GASP and MOZAIC coordinates using the ERA40 data at their full vertical resolution of 60 levels and at a horizontal resolution of $1^{\circ} \times 1^{\circ}$.

To guarantee that only reliable ERA40 information was used at any given time and place, aircraft measurements were only considered in the averaging process when aircraft and ERA40 temperatures deviated less than $3 \mathrm{~K}$ from each other. Applying this constraint, 3.7\% of the pre-processed GASP data (cf. Sect. 2.1.3) have not been used.

To compute vertical ozone profiles scaled by the local tropopause as presented in Sect. 4.1, the difference between the potential temperatures at cruise altitude, derived from the aircraft data, and at the $2 \mathrm{PVU}$ tropopause, interpolated from ERA40 fields, was used to bin the aircraft data in layers of $10 \mathrm{~K}$ width around the dynamical tropopause covering a vertical range of $-45 \mathrm{~K}$ to $+65 \mathrm{~K}(\Delta \theta=-40 \mathrm{~K} \bumpeq[-45 \mathrm{~K}$, $-35 \mathrm{~K}],-30 \mathrm{~K} \triangleq[-35 \mathrm{~K},-25 \mathrm{~K}]$, etc.). The considered potential temperature distances from the tropopause translate to a vertical data range of approximately $-5.5 \mathrm{~km}$ to $+4.5 \mathrm{~km},-4.5 \mathrm{~km}$ to $+4 \mathrm{~km}$, and $-1.5 \mathrm{~km}$ to $+4 \mathrm{~km}$ around the tropopause in the subtropics, midlatitudes, and high latitudes, respectively. The climatological UT ozone values presented in Sect. 4.2 were calculated by averaging over all measurements below the $2 \mathrm{PVU}$ tropopause $(\Delta \theta<0 \mathrm{~K})$. Approximately $2 \%$ of these data points were nevertheless assigned a $\mathrm{PV}$ value larger than 2 indicative of a second tropopause below the one registered in the ERA40 files due to the presence of a fold. These points were removed before averaging. $90 \%$ of all data classified in this way as UT values were collected in a vertical range of approximately $-0.1 \mathrm{~km}$ to $-4 \mathrm{~km}$ and $-0.2 \mathrm{~km}$ to $-6 \mathrm{~km}$ at middle $\left(40^{\circ} \mathrm{N}-60^{\circ} \mathrm{N}\right)$ and subtropical $\left(20^{\circ} \mathrm{N}-40^{\circ} \mathrm{N}\right)$ latitudes, respectively.

For the analysis in the lower stratosphere, where diabatic processes only play a minor role and ozone is mostly dominated by large-scale quasi-horizontal transport, all data have additionally been arranged into the equivalent latitude/potential temperature framework (Butchart and Remsberg, 1986). The main advantage of using this coordinate system is that much of the ozone variability in the longitudinal structure is removed such that computing quasi-zonal means at equivalent latitudes constitutes a meaningful diagnosis tool (e.g., Hegglin et al., 2006). After binning relative to the dynamical tropopause and computing quasi-zonal means, the data were finally averaged over specific equivalent latitude (EL) ranges chosen to represent middle and high latitudes.

For the comparison with MOZAIC in the UT, we have calculated regional averages for specific regions listed in Table 3 
Table 3. Definition of regions for calculating GASP regional averages of tropospheric ozone. Regions are listed in order as discussed in the text.

\begin{tabular}{lccc}
\hline Region & Acronym & Latitudes & Longitudes \\
\hline Atlantic & ATL & $45^{\circ} \mathrm{N}-55^{\circ} \mathrm{N}$ & $60^{\circ} \mathrm{W}-10^{\circ} \mathrm{W}$ \\
Europe & EUR & $35^{\circ} \mathrm{N}-55^{\circ} \mathrm{N}$ & $10^{\circ} \mathrm{W}-30^{\circ} \mathrm{E}$ \\
Northeastern USA & NE USA & $40^{\circ} \mathrm{N}-50^{\circ} \mathrm{N}$ & $90^{\circ} \mathrm{W}-60^{\circ} \mathrm{W}$ \\
Western USA & W USA & $30^{\circ} \mathrm{N}-50^{\circ} \mathrm{N}$ & $125^{\circ} \mathrm{W}-105^{\circ} \mathrm{W}$ \\
Northern Japan & N JP & $40^{\circ} \mathrm{N}-50^{\circ} \mathrm{N}$ & $115^{\circ} \mathrm{E}-170^{\circ} \mathrm{E}$ \\
Southern Japan & S JP & $30^{\circ} \mathrm{N}-40^{\circ} \mathrm{N}$ & $115^{\circ} \mathrm{E}-170^{\circ} \mathrm{E}$ \\
Northern India & N IND & $20^{\circ} \mathrm{N}-30^{\circ} \mathrm{N}$ & $60^{\circ} \mathrm{E}-90^{\circ} \mathrm{E}$ \\
Southern India & S IND & $5^{\circ} \mathrm{N}-20^{\circ} \mathrm{N}$ & $60^{\circ} \mathrm{E}-90^{\circ} \mathrm{E}$ \\
South China & S CHINA & $5^{\circ} \mathrm{N}-25^{\circ} \mathrm{N}$ & $90^{\circ} \mathrm{E}-130^{\circ} \mathrm{E}$ \\
Midlatitude Northeast Pacific & ML NEP & $30^{\circ} \mathrm{N}-50^{\circ} \mathrm{N}$ & $160^{\circ} \mathrm{W}-125^{\circ} \mathrm{W}$ \\
Subtropical Northeast Pacific & ST NEP & $10^{\circ} \mathrm{N}-30^{\circ} \mathrm{N}$ & $180^{\circ}-125^{\circ} \mathrm{W}$ \\
\hline
\end{tabular}

(see also Fig. 7). Seasonal means were calculated to qualitatively compare mean annual cycles between GASP and MOZAIC in the selected regions.

\section{GASP climatology}

In this section, we present the GASP climatology in comparison with MOZAIC and the literature. While in Sect. 4.1, climatological zonal mean profiles at subtropical, midlatitude, and high latitudes are discussed, Sect. 4.2 focuses on UT ozone in different regions of the northern hemisphere. Section 4.3 gives new comprehensive information on the spatial and seasonal distribution of UT ozone over the Pacific Ocean. Note that the MOZAIC climatology is added for the purpose of highlighting the reliability of GASP ozone. A quantitative comparison deducing long-term changes will be dealt with in a forthcoming paper.

\subsection{Zonal mean profiles}

Figure 6 presents GASP climatological mean seasonal UT/LS ozone profiles for specific latitude ranges. In the UT, all data are binned according to their geographical latitudes. In the LS, geographical latitudes were used for $20^{\circ} \mathrm{N}-40^{\circ} \mathrm{N}$ and equivalent latitudes for $40^{\circ} \mathrm{N}-60^{\circ} \mathrm{N}$ and $60^{\circ} \mathrm{N}-80^{\circ} \mathrm{N}$. The latitudinal and vertical dependence is compared with MOZAIC climatological profiles. When comparing the two data sets, it has to be kept in mind that differences may also arise due to long-term changes in UT/LS ozone.

At all latitudes, GASP [MOZAIC] vertical gradients are very small in the UT below $-15 \mathrm{~K}(0.1-0.3 \mathrm{ppbv} / \mathrm{K})[0.1-$ $0.5 \mathrm{ppbv} / \mathrm{K}]$. In the uppermost troposphere $(-10 \mathrm{~K} \stackrel{\wedge}{=} 15$ to $-5 \mathrm{~K})$, ozone already increases at $2.4-2.7 \mathrm{ppbv} / \mathrm{K}[2.2-$ $2.3 \mathrm{ppbv} / \mathrm{K}]$. Gradients are largest in the LS (4 to $10 \mathrm{ppbv} / \mathrm{K}$ ) [3-11 ppbv/K].

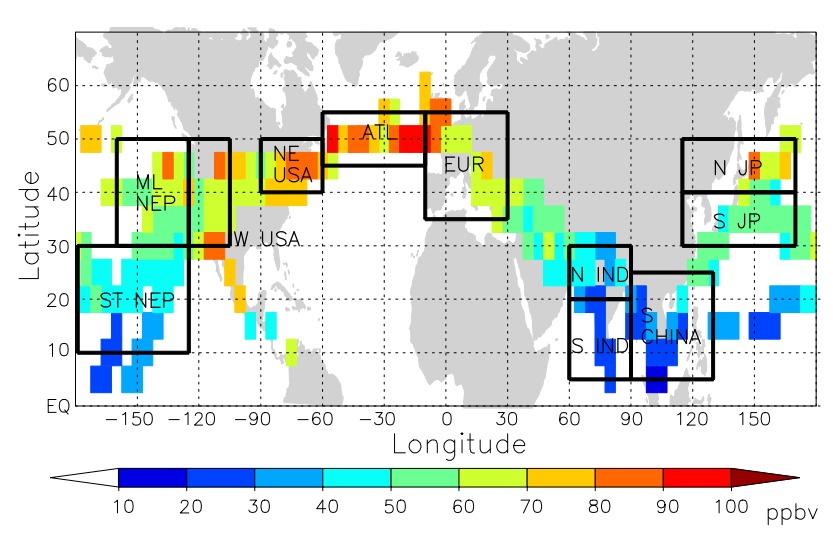

Fig. 7. Definition of regions for calculating regional means of UT ozone. Colours: GASP climatological mean UT ozone in JJA, $5^{\circ} \times 5^{\circ}$ averages, displayed where number of flights is greater than 5 and number of measurements larger than 20 in a given box. For detailed latitudinal/longitudinal specifications of regions see Table 3 .

A typical lower stratospheric seasonal cycle is evident at mid- and high latitudes with highest values in spring, lower values in winter and summer and lowest in autumn. Due to the higher altitude of the tropopause in the subtropics, fewer GASP (and MOZAIC) data were recorded in the stratosphere between $20^{\circ} \mathrm{N}$ and $40^{\circ} \mathrm{N}$ than at higher latitudes. For this reason, as well as due to fewer flights at these latitudes, the LS seasonal cycle is not completely described at altitudes above $40 \mathrm{~K}$ above the tropopause. Yet, the existing data point to a similar seasonal cycle as at middle and high latitudes.

The comparison of the GASP and MOZAIC LS mean profiles shows very good overall agreement in terms of vertical gradients and absolute values during all seasons of the year. Larger differences only occur where only few data were sampled, such as in winter and more significantly in summer at subtropical latitudes at the upper layers (Fig. 6a, DJF, JJA), or where it must be suspected that long-term changes due to stratospheric ozone depletion lead to different LS ozone 

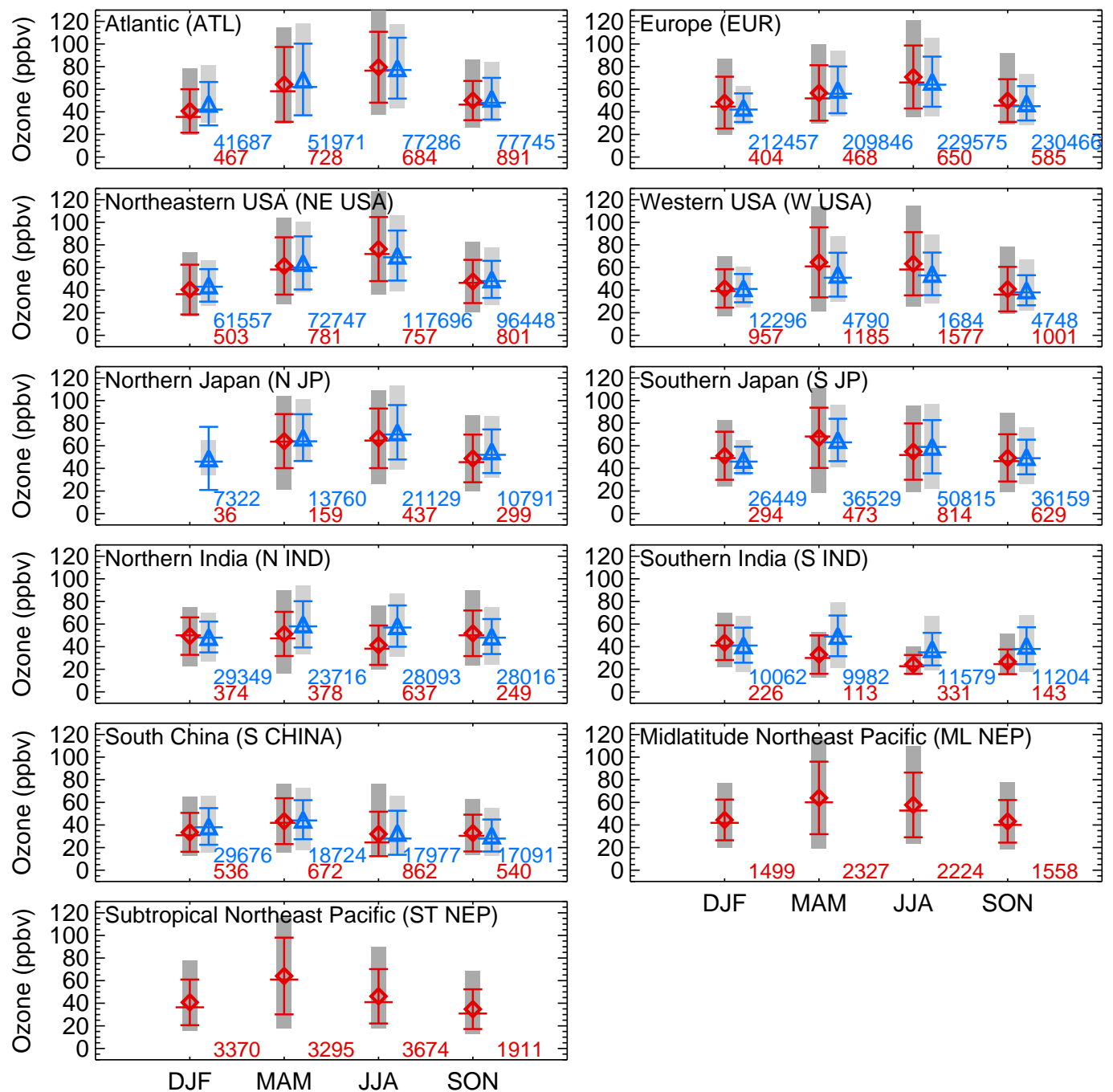

Fig. 8. Climatological mean and median ozone in the upper troposphere $(\Delta \theta<0 \mathrm{~K})$ as a function of season for different regions of the world ordered as discussed in text (specifications of regions cf. Table 3). GASP means (medians) 1975-1979: red diamonds (horizontal bars), MOZAIC means (medians) 1994-2001: blue triangles (horizontal bars). Vertical bars indicate one standard deviation, vertical grey boxes central $90 \%$. Numbers at the bottom give number of measurements in each region and season, red: GASP data, blue: MOZAIC data.

abundance, such as in winter at high latitudes (Fig. 6c, DJF). Seasonality and order of magnitude of ozone mixing ratios also agree well with ozonesonde measurements (e.g., Logan et al., 1999, their Fig. 10) and a UT/LS ozone climatology of the period 1984-2005 derived from SAGE II satellite measurements (Wang et al., 2006, their Fig. 3).

In the subtropical UT, the seasonal cycle is similar to that in the LS with largest values in spring and smallest in autumn suggesting a marked stratospheric influence. At northern midlatitudes, ozonesonde, aircraft, and satellite observations show that UT ozone concentrations are usually lowest in winter and exhibit a broad maximum between spring and summer with somewhat higher values in summer (e.g., Logan, 1999; Thouret et al., 1998a; Brunner et al., 2001; Wang et al., 2006) which is believed to reflect the influence of both photochemistry and stratosphere-troposphere exchange (STE) peaking in summer and spring, respectively (e.g., Stohl et al., 2003). This seasonality is also reflected in the GASP and MOZAIC data (see also Sect. 4.2). At high latitudes, due to a low altitude tropopause, most measurements were taken in the LS. Hence, the GASP data reveal only little insight into UT ozone there.

4.2 UT ozone in different regions of the Northern Hemisphere

Since the factors affecting UT ozone including transport from regions of ozone precursor sources, photochemistry, vertical mixing, and transport from the stratosphere may vary with region, we have computed regional averages of UT ozone measurements for both GASP and MOZAIC data (Table 3). Figure 7 shows the domains used for averaging on a geographic map. To document the reasoning for the choice 
of regions, the GASP mean UT ozone distribution for the summer season is underlaid. In specific cases such as over Northern Japan (N JP), the methodology results in large averaging boxes that are only partly representative of GASP or MOZAIC data coverage: whereas GASP flights approach Japan from the east, MOZAIC data cover the region west of Japan (Fig. 1). For seasonal averaging, arithmetic means and medians were computed using all seasonal data from the five-year period.

In some regions the sample size is limited in certain seasons and/or years. Thus, some averages may not be representative for the five GASP years, and designating these averages "climatology" may not be justified. Indeed, a large fraction of the GASP data was recorded during 1978 and therefore, many averages are more or less biased toward this year (cf. number of GASP records available in each region in Table A1).

The seasonal variation of GASP and MOZAIC UT ozone in different regions is shown in Fig. 8. Besides the Pacific region not covered by MOZAIC, GASP also provides comprehensive information on the seasonal cycle of UT ozone over the western United States complementing ozonesonde measurements at Trinidad Head, California.

Tropospheric ozone concentrations and the seasonal cycle can be quite different in different regions of the world (e.g., Logan, 1985, 1999) (Fig. 8). Over Europe (EUR), the Atlantic (ATL), and the northeastern part of the United States (NE USA), the typical midlatitude seasonal cycle is found (GASP summer mean: 70-80 ppbv, winter mean: $40 \mathrm{ppbv}$ (ATL, NE USA), 50 ppbv (EUR)). Interestingly, mean summer mixing ratios over these regions are higher in the 1970s than in the 1990s. At least for the ATL and the NE USA regions, this can be largely explained by the bias of GASP data towards the year 1978 (Table A1) when unusually high ozone concentrations were observed in the UT/LS (Wozniak, 1997).

Over the western parts of the United States (W USA), UT ozone exhibits a different seasonal cycle more similar to the cycle in the LS. This pattern does not change when restricting the latitude range to lower $\left(30^{\circ} \mathrm{N}-40^{\circ} \mathrm{N}\right)$ or higher midlatitudes $\left(40^{\circ} \mathrm{N}-50^{\circ} \mathrm{N}\right)$ (not shown). During spring, mean ozone mixing ratios are significantly higher than over the northeastern US, the Atlantic, or Europe. In contrast, summer values are relatively low (65 ppbv) compared to mixing ratios over the northeastern US, Atlantic, and Europe (70-80 ppbv). Recent ozonesonde data from Trinidad Head, California, of the period 1997-2002, are in agreement with the seasonality and concentrations observed by GASP (Newchurch et al., 2003). They find a spring maximum in UT ozone that they relate to an enhanced frequency of STE episodes and/or higher intensities of these events in terms of the amount of ozone exchanged compared to three other stations. The findings are corroborated by the study of Stohl et al. (2003) who showed that a preferred area of deep downward STE is at the end of the Pacific stormtrack, located above the U.S. west coast, maximising in winter. The implications of STE for tropospheric ozone could be shown to result in maximum ozone concentrations during spring (Stohl et al., 2003; their Fig. 5). Note that the MOZAIC spring and summer concentrations are much lower than the GASP values. These differences will be discussed in more detail in the follow-up paper on long-term changes.

It is also worthwhile to notice the resemblance between the pattern of summertime UT ozone over the United States in Fig. 7 and the distribution of surface ozone (e.g., Fiore et al., 1998, their Plate 1) with lower values across the west to the midwest and higher concentrations in the east. In a narrow south-north oriented region along the west coast, elevated ozone levels are found both in the surface and in the GASP data. At the surface, high summer ozone over southern California is connected to air pollution, a well-known phenomenon especially prominent from the 1950 s to the 1970 s (e.g., Grosjean, 2003). In the UT at $30^{\circ} \mathrm{N}$ and $110^{\circ} \mathrm{W}-$ $115^{\circ} \mathrm{W}$ in Fig. 7 , summer ozone amounts to $>80 \mathrm{ppbv}$ (dark orange pixels in Fig. 7) being significantly higher than in the surrounding regions. These high UT mixing ratios may thus be speculated to be connected to ozone smog episodes over southern California. Even though a persistent temperature inversion over the Los Angeles basin in summer normally prevents boundary layer air from entering the free troposphere during summer (e.g., Lu and Turco, 1996), upslope mountain thermal winds in the San Gabriel mountains near Los Angeles can create a chimney effect injecting polluted air directly into the free troposphere (Lu and Turco, 1995, 1996). Further studies, e.g. using back trajectories, would clearly be required to better understand the connection between the photochemical smog at the surface and the high values in the UT observed by GASP.

Over Northern Japan (N JP), GASP data are mostly from 1978 (Table A1) and may therefore not be representative of longer-term means. Still, the seasonal ozone evolution is consistent with that of MOZAIC and values are comparable. Over midlatitude N JP and subtropical-midlatitude Southern Japan (S JP), differing types of seasonal cycles are found consistent for GASP and MOZAIC. Whereas over $\mathrm{N}$ JP, high values of GASP ozone extend from spring to summer (65 ppbv), the southern parts show a spring maximum (65 ppbv) and much lower values in summer (55 ppbv). Japanese ozonesonde observations (Logan, 1985, 1999; Liu et al., 2002; Naja and Akimoto, 2004) qualitatively agree with these features. The reduced summer values over S JP are associated with monsoonal intrusion of low-ozone air from the tropical Pacific. Further north, the influence of the monsoon decreases, and the summer maximum at Sapporo results from photochemical production, typical of the northern midlatitudes.

Over northern India (N IND), southern India (S IND), and South China (S CHINA), GASP and MOZAIC data show springtime maxima. The only exception from this pattern is over S IND for the GASP period, where no spring max- 
imum is found. This might be due to the restricted number of measurements available (113), out of which almost $90 \%$ were recorded during 1977 (Table A1). UT spring maxima in the subtropical to tropical atmosphere as observed by the GASP and MOZAIC programs may in fact be a common phenomenon as there are further measurement programs and campaigns which yielded similar results. High springtime UT ozone, for instance, was observed on the flight route between Bombay and Hong Kong during the 1995/96 NOXAR project (Brunner et al., 2001) and between $15^{\circ} \mathrm{N}$ and $20^{\circ} \mathrm{S}$ over the Indian Ocean during the 1998/1999 INDOEX campaigns (Zachariasse et al., 2000, 2001; De Laat, 2002).

Ozone mixing ratios over N IND are comparable to those over S JP in autumn and winter, but they are somewhat lower in spring, and much lower during summer (40 ppbv). Over S IND, UT ozone mixing ratios are generally very low ranging from 35-45 ppbv in winter and spring to about $25 \mathrm{ppbv}$ in summer and autumn. The summer minimum over $\mathrm{N}$ IND and S IND can be related to convective activity during the summer monsoon. During this season, ground stations in India report the lowest $\mathrm{NO}_{\mathrm{x}}$ and ozone concentrations (Naja and Lal, 1996, 2002; Kulshreshta et al., 1997). Intensive, but electrically little active monsoonal convection carries the $\mathrm{NO}_{\mathrm{x}}$ and ozone poor air masses to the middle and upper troposphere. This is supported by NOXAR measurements, which show pronounced minima in nitrogen oxides and ozone at cruising levels on the route between Bombay and Hong Kong in summer (Brunner et al., 2001). However, a summer minimum in UT ozone is not seen in the MOZAIC data over N IND, although GASP and MOZAIC flight paths cover the same routes (not shown). A potential explanation may be the strong increases in ozone precursor emissions over the last decades over the Indian subcontinent (e.g., van Aardenne et al., 2001) which might also impact UT ozone concentrations. A more detailed discussion will be given in the follow-up paper on long-term changes.

Over the South China region (S CHINA), GASP and MOZAIC measurements indicate that UT ozone concentrations vary only little between summer, autumn, and winter (30-35 ppbv). As is also characteristic for the North and South Indian regions, UT ozone over South China also exhibits a springtime maximum ( $45 \mathrm{ppbv}$ ) for both GASP and MOZAIC periods.

\subsection{Upper tropospheric ozone in the Pacific region}

Until today, most studies documenting the ozone content and seasonality of the northern hemisphere Pacific region have been confined to analyses of individual ozonesonde stations (e.g. Logan et al., 1999; Oltmans et al., 2001; Liu et al., 2002; Oltmans et al., 2004), evaluations of individual aircraft campaigns (e.g., Singh et al., 1996; Zhang et al., 2003; Wild et al., 2003), and tropospheric ozone residuals from satellite observations (e.g., Fishman et al., 2003). The climatology presented by DiNunno et al. (2003) includes 10 aircraft cam- paigns in 20 years. However, it is based on individual flights separated by large time intervals. It is also confined to the spring and autumn seasons, and restricted to the central and eastern North Pacific region.

The regular GASP measurements provide a more comprehensive picture of the seasonality, horizontal distribution, and latitudinal dependence of UT ozone over the Pacific. While data were recorded regularly during all five years (cf. also ST NEP and ML NEP in Table A1), a significant fraction was collected during 1978. For the winter and spring seasons, the fraction amounts to $32-41 \%$, for the summer and autumn seasons to $64-75 \%$ (calculated for $10^{\circ} \mathrm{N}-50^{\circ} \mathrm{N}$, $\left.150^{\circ} \mathrm{E}-125^{\circ} \mathrm{W}\right)$.

Over the eastern midlatitude and subtropical Northeast Pacific (Fig. 8, ML NEP and ST NEP, respectively), the seasonal cycles and ozone concentrations are very similar to the conditions over the western US (Fig. 8, W USA, cf. previous section). Most probably, the lacking summer maximum in UT ozone over the Pacific is associated with clean air masses prevalent in this region. The similar seasonal cycle over the western United States suggests a major influence of air brought in from the Pacific. Over the subtropical Northeast Pacific (ST NEP), GASP UT ozone averages are in good agreement with more recent UT ozonesonde measurements at Hilo, Hawaii $\left(20^{\circ} \mathrm{N}, 155^{\circ} \mathrm{W}\right)(1985-1990)$ (Oltmans et al., 1996; their Fig. 5, $300 \mathrm{hPa}$ ). The spring maximum apparent in both aircraft and ozonesonde observations was explained to be partly caused by long-range transport of Asian pollution leading to photochemical production of ozone (Oltmans et al., 1996; Wang et al., 1998; Liu et al., 2002). Other parts are likely to be associated with descending air motion from north of $30^{\circ} \mathrm{N}$ contributing stratospheric air high in ozone (Oltmans et al., 1996).

Seasonal mean ozone distributions (Fig. 9) reveal further features of UT ozone over the Pacific: (1) over large parts of the eastern midlatitude Pacific $\left(30^{\circ} \mathrm{N}-40^{\circ} \mathrm{N}, 150^{\circ} \mathrm{W}-\right.$ $120^{\circ} \mathrm{W}$ ), summer UT ozone (averages $54 \mathrm{ppbv}$ at $30^{\circ} \mathrm{N}$, $58 \mathrm{ppbv}$ at $35^{\circ} \mathrm{N}-40^{\circ} \mathrm{N}$, see dark green coded pixels) is lower than over the American continent (average $64 \mathrm{ppbv}$, light green coded pixels). The differences probably reflect a reduced influence of photochemistry in the unpolluted air masses over the ocean. (2) Tropical ozone at latitudes $<20^{\circ} \mathrm{N}$ is generally low and a clear seasonal cycle is not discernible. Interestingly, in spring and even more so in summer, the concentrations at $170^{\circ} \mathrm{W}$ to $165^{\circ} \mathrm{W}(20-25 \mathrm{ppbv})$ are approximately 5 to $15 \mathrm{ppbv}$ lower than further east at $160^{\circ} \mathrm{W}-145^{\circ} \mathrm{W}$. During boreal winter, no clear west-east differences are discernible. For the autumn season, GASP does not provide enough data to assess longitudinal variations in the tropics. The tropospheric ozone residual (TOR) retrieval derived from the TOMS and SBUV instruments for the period 1979 to 2000 (Fishman et al., 2003, their Fig. 1) qualitatively agrees with these distributions, as well as with their seasonal differences. The region of low tropospheric ozone columns and low UT ozone over the central Pacific 


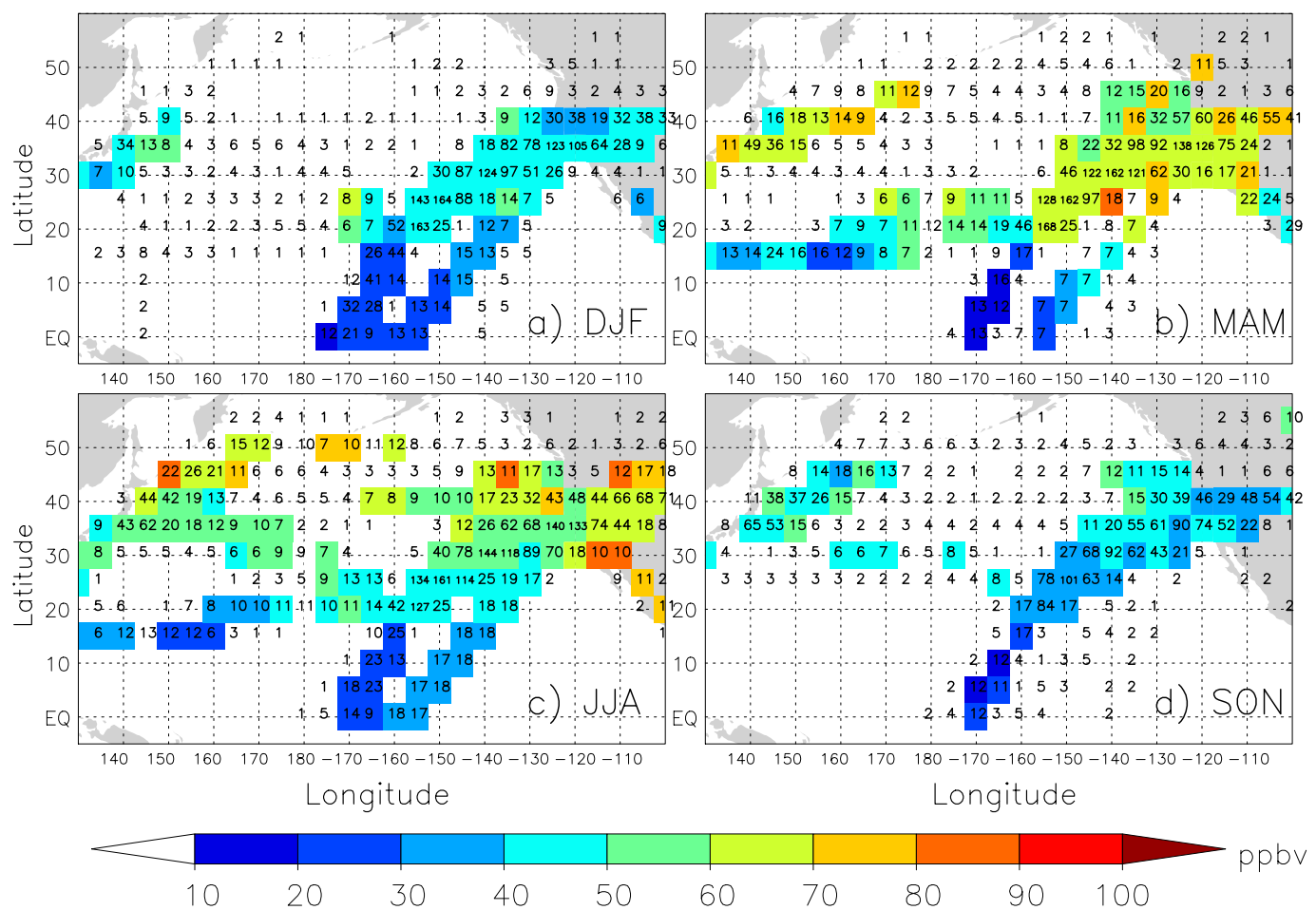

Fig. 9. Horizontal distribution of climatological mean UT ozone $(\Delta \theta<0 \mathrm{~K})$ (ppbv) over the Pacific region: (a) DJF, (b) MAM, (c) JJA, (d) SON. Numbers indicate number of flights in a $5^{\circ} \times 5^{\circ}$ box. Five-year averages are only displayed where number of flights is greater than 5 and the number of measurements is larger than 20 in a box.

coincides with the warm pool area and enhanced convective activity in the Intertropical Convergence Zone (ITCZ). The lowest troposphere over the equatorial Pacific acts as a chemical ozone sink, where ozone is destroyed by photochemical cycles involving water vapour and solar ultraviolet radiation (e.g., Kley et al., 1997). Low ozone concentrations in the equatorial marine boundary layer have also been reported in earlier studies (Liu et al., 1983, Piotrowicz et al., 1986, 1991; Johnson et al., 1990; Thompson et al., 1993). This ozonepoor air can be lifted upwards in tropical convection leading to low UT concentrations (e.g., Kley, 1997). However, convective activity is suppressed in the downward branch of the Walker circulation over the eastern Pacific region, and therefore UT air masses are much less affected by ozonepoor air from the marine boundary layer. Another mechanism contributing to the elevated values over the eastern $\mathrm{Pa}$ cific may be large-scale advection of higher-ozone air masses from northern and central America in association with southward flow along the eastern flank of the UT high pressure centre over the Western Pacific (e.g., Gregory et al., 1999; DiNunno et al., 2003).

The latitudinal dependence of UT ozone over the Northeast Pacific (see Fig. 10 for meridional cross sections at $150^{\circ} \mathrm{W}$ to $130^{\circ} \mathrm{W}$ ) indicates that tropical ozone mixing ratios are much lower than subtropical and midlatitude values during all seasons. The seasonal cycle in the tropics and subtropics is characterized by largest values in spring

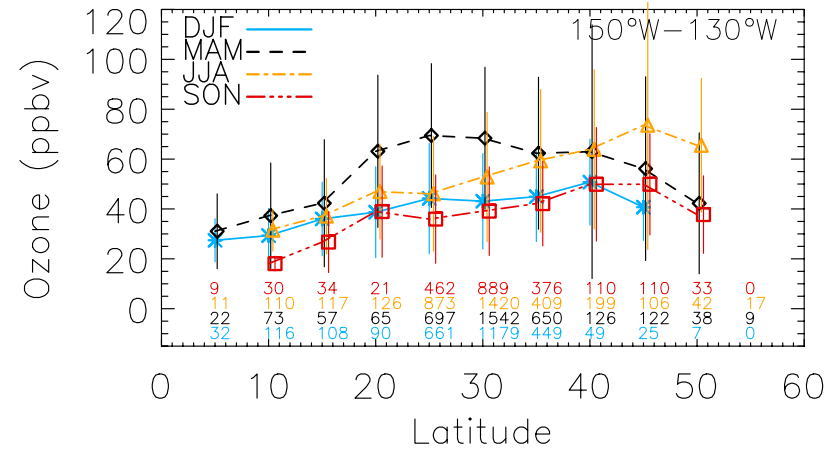

Fig. 10. Meridional cross section of mean UT ozone $(\Delta \theta<0 \mathrm{~K})$ (ppbv) for the longitude range $150^{\circ} \mathrm{W}$ to $130^{\circ} \mathrm{W}$ as function of season. Vertical bars denote standard deviation. DJF: blue solid line, asterisks, MAM: black dashed line, diamonds, JJA: orange dash-dot line, triangles, SON: red dash-dot-dot line, squares. Averages are only displayed when more than 20 records are available. Number of records is presented at the bottom for each latitude and season, from DJF upward to SON.

(20-25 ppbv and 65-70 ppbv, respectively), lower and comparable mixing ratios in summer and winter, and lowest in autumn (20-25 ppbv and 35-40 ppbv, respectively) (cf. also Sect. 4.1). A plausible explanation for the spring maximum could be STE in the vicinity of the subtropical jetstream (Stohl et al., 2003, their Figs. 3a and 5). The latitudes between $30^{\circ} \mathrm{N}$ and $40^{\circ} \mathrm{N}$ can be considered a transition zone 
between subtropical and midlatitude regimes with respect to seasonality. There, spring (summer) mixing ratios decrease (increase) with latitude. North of $40^{\circ} \mathrm{N}$, the UT ozone seasonal cycle is of midlatitude type. Note that despite this latitudinal dependence, a spring maximum is still found for the ML NEP region, representative for $30^{\circ} \mathrm{N}-50^{\circ} \mathrm{N}$ (Table 3), which is due to more measurements available in the southern parts of the region (see number of records in Fig. 10) biasing the average. Later measurements from the eastern Pacific aircraft campaign database for the 1978-1999 period (DiNunno et al., 2003; their Fig. 5a and b) agree favourably with the GASP data in the $8-9 \mathrm{~km}$ altitude region: As observed by GASP, tropical spring ozone mixing ratios are very low (20 to $40 \mathrm{ppbv}$ ), highest in the latitude range of $15^{\circ} \mathrm{N}$ to $25^{\circ} \mathrm{N}$ (60 to $80 \mathrm{ppbv}$ ), and slightly lower further northward (40 and $60 \mathrm{ppbv}$ ). During autumn, ozone from the aircraft database also exhibits low values over a broad latitude range.

\section{Summary and conclusions}

In this study, we have presented the UT/LS ozone data set of the GASP aircraft program conducted by NASA between 1975 and 1979. The comparison with independent observations and the results of two cases of nearly coincident flights of two GASP airliners along the same flight route indicate that the measurements are of high quality. This conclusion is supported by the fact that GASP included an extensive quality assurance and control program, and that a wellestablished ozone measurement technique (UV photometry) was applied, which hast also been used in the MOZAIC and NOXAR programs in a similar way. The most critical point in terms of accuracy was the loss of ozone in the sampling system and the pump used for pre-compressing the sample gas. The problem was significantly reduced in early 1977 when the pump diaphragms were changed to a different material. Depending on the error in determining the ozone destruction constant, the data set was estimated to have an overall uncertainty of $9 \%$ or $3 \mathrm{ppb}$ whichever is greater for the first two years and $4 \%$ or $3 \mathrm{ppb}$ for the remaining years. Even though the frequent exchange of instruments and calibrations in the laboratory assured a stable operation over the course of the GASP program, the data provide no further indications that the stated uncertainty holds for all individual flights. The results from the two near simultaneous flights are not sufficiently conclusive either to verify or disprove the overall uncertainty. Before using the data in this study, a general $9 \%$ high bias that was due to inaccurate calibration of the GASP secondary transfer standard, had to be corrected for. Furthermore, some suspiciously low ozone readings were removed from the data set.

The GASP data set has been used to establish a largescale ozone climatology of the UT/LS in the nineteen seventies. In particular, climatological information on the ozone content over the Pacific Ocean has been derived, a region where large-scale long-term measurements of the UT/LS have largely been missing.

Climatologies were computed for the LS and UT separately. In the LS, at middle and high latitudes, characteristic ozone profiles were obtained showing the expected seasonal cycle with highest values in spring, lower values in winter and lowest in autumn. Although measurements in the subtropical stratosphere are not as numerous, they indicate the same seasonality.

In the UT, aircraft measurements were averaged over specific regions providing large-scale information on midlatitude and subtropical to tropical UT ozone in the nineteen seventies. The seasonal cycles and ozone concentrations are largely different depending on the region considered and can be described as follows:

- Over the midlatitude regions of the northeastern United States, the Atlantic, Europe, and Northern Japan, UT ozone shows low values in autumn and winter, higher values in spring, and a maximum in summer.

- A spring maximum occurs over the western United States, the midlatitude and subtropical northeastern Pacific, and over subtropical-midlatitude Southern Japan. Over Southern Japan, much lower mixing ratios are found in summer than over Northern Japan, qualitatively consistent with measurements from MOZAIC.

- A pronounced summer minimum is found over Northern and Southern India.

The GASP data set provides particularly valuable information on the vertical and horizontal distribution of UT/LS ozone above the NH Pacific region:

- Over large regions of the eastern midlatitude Pacific summer UT ozone is lower by 5 to $10 \mathrm{ppbv}$ than over the American continent.

- In spring and in summer, tropical UT ozone is lower by 5 to $15 \mathrm{ppbv}$ between $170^{\circ} \mathrm{W}$ and $165^{\circ} \mathrm{W}$ than further east at $160^{\circ} \mathrm{W}-145^{\circ} \mathrm{W}$.

- Ozone mixing ratios are much lower over the tropics than at subtropical and middle latitudes during all seasons. At tropical to subtropical latitudes, the seasonal cycle is dominated by a spring maximum, whereas north of $40^{\circ} \mathrm{N}$, the UT ozone seasonal cycle is of midlatitude type characterized by highest mixing ratios in summer.

General agreement with other data, in particular with MOZAIC, is found in terms of seasonality and absolute concentrations. GASP is thus a valuable data set to compare with more recent UT/LS aircraft data such as MOZAIC to deduce long-term changes of UT/LS ozone, which will be addressed in a forthcoming publication. The GASP data will also be of great value for other applications including validation of model simulations of past ozone and as "transfer 
standard" for cross-validating tropospheric ozone observations from sondes in the 1970s, for which the quality has never been thoroughly assessed.

Acknowledgements. This work has been carried out in the framework of the project RETRO sponsored by the European Union under contract EVK2-CT-2002-00170. We thank Andrew Detwiler for providing us the GASP data. Special thanks also goes to the MOZAIC team for making their data available to us. In this regard, the authors also gratefully acknowledge the strong support of the MOZAIC program by the European Communities, EADS, Airbus, and the airlines Lufthansa, Austrian, and Air France who have carried the MOZAIC equipment free of charge since 1994. ERA40 reanalysis data have been provided by the NOAACIRES Climate Diagnostics Center, Boulder, Colorado, USA, from their Web site at http://www.cdc.noaa.gov/. The processed GASP data can be downloaded from the ETHmeg database (http://www.megdb.ethz.ch). Finally, we thank Jennifer A. Logan, A. Volz-Thomas, and an anonymous reviewer for their constructive and helpful suggestions and comments.

Edited by: A. Volz-Thomas 


\section{Appendix A}

Table A1. Number of GASP records in upper tropospheric regions (coordinate specification in Table 3) as function of season and year of observation.

\begin{tabular}{|c|c|c|c|c|c|c|c|}
\hline \multirow[t]{2}{*}{ Season } & \multirow[t]{2}{*}{ Number years } & \multicolumn{5}{|c|}{ Number per Year } & \multirow[t]{2}{*}{ Number of records } \\
\hline & & 1975 & 1976 & 1977 & 1978 & 1979 & \\
\hline \multicolumn{8}{|c|}{ Atlantic (ATL) } \\
\hline DJF & 3 & - & 103 & - & 119 & 245 & 467 \\
\hline MAM & 5 & 67 & 205 & 77 & 94 & 285 & 728 \\
\hline JJA & 4 & - & 38 & 11 & 574 & 61 & 684 \\
\hline SON & 3 & - & 307 & 30 & 554 & - & 891 \\
\hline Sum per year & & 67 & 653 & 118 & 1341 & 591 & 2770 \\
\hline Fraction $(\%)$ & & 2.4 & 23.6 & 4.3 & 48.4 & 20.8 & \\
\hline \multicolumn{8}{|c|}{ Europe (EUR) } \\
\hline DJF & 4 & - & 47 & 128 & 122 & 107 & 404 \\
\hline MAM & 5 & 37 & 96 & 199 & 37 & 99 & 468 \\
\hline JJA & 4 & - & 202 & 172 & 256 & 20 & 650 \\
\hline $\mathrm{SON}$ & 3 & - & 73 & 140 & 372 & - & 585 \\
\hline Sum per year & & 37 & 418 & 639 & 787 & 226 & 2107 \\
\hline Fraction $(\%)$ & & 1.8 & 19.8 & 30.3 & 37.4 & 10.7 & \\
\hline \multicolumn{8}{|c|}{ Midlatitude Northeast Pacific (ML NEP) } \\
\hline DJF & 5 & 85 & 288 & 113 & 620 & 393 & 1492 \\
\hline MAM & 5 & 230 & 578 & 438 & 834 & 247 & 2327 \\
\hline JJA & 5 & 238 & 88 & 182 & 1622 & 94 & 2224 \\
\hline SON & 4 & 164 & 150 & 207 & 1037 & - & 1558 \\
\hline Sum per year & & 717 & 1104 & 940 & 4113 & 734 & 7608 \\
\hline Fraction $(\%)$ & & 9.4 & 14.5 & 12.4 & 54.1 & 9.6 & \\
\hline \multicolumn{8}{|c|}{ Western USA (W USA) } \\
\hline DJF & 5 & 29 & 234 & 54 & 361 & 279 & 957 \\
\hline MAM & 5 & 134 & 337 & 121 & 460 & 133 & 1185 \\
\hline JJA & 5 & 179 & 20 & 33 & 1317 & 28 & 1577 \\
\hline $\mathrm{SON}$ & 4 & 166 & 97 & 48 & 690 & - & 1001 \\
\hline Sum per year & & 508 & 688 & 256 & 2828 & 440 & 4720 \\
\hline Fraction $(\%)$ & & 10.8 & 14.6 & 5.4 & 59.9 & 9.3 & \\
\hline \multicolumn{8}{|c|}{ Northeastern USA (NE USA) } \\
\hline DJF & 5 & 8 & 103 & 5 & 196 & 191 & 503 \\
\hline MAM & 5 & 64 & 255 & 110 & 171 & 173 & 781 \\
\hline JJA & 5 & 34 & 45 & 14 & 628 & 36 & 757 \\
\hline SON & 4 & 56 & 267 & 87 & 391 & - & 801 \\
\hline Sum per year & & 162 & 670 & 224 & 1386 & 400 & 2842 \\
\hline Fraction (\%) & & 5.7 & 23.6 & 7.9 & 48.8 & 14.1 & \\
\hline \multicolumn{8}{|c|}{ Northern Japan (N JP) } \\
\hline DJF & 2 & - & - & - & 10 & 26 & 36 \\
\hline MAM & 4 & 11 & 1 & - & 111 & 36 & 159 \\
\hline JJA & 3 & - & 10 & - & 412 & 15 & 437 \\
\hline SON & 3 & - & 150 & 47 & 102 & - & 299 \\
\hline Sum per year & & 11 & 161 & 47 & 635 & 77 & 931 \\
\hline Fraction $(\%)$ & & 1.2 & 17.3 & 5.0 & 68.2 & 8.3 & \\
\hline
\end{tabular}


Table A1. Continued.

\begin{tabular}{|c|c|c|c|c|c|c|c|}
\hline \multirow[t]{2}{*}{ Season } & \multirow[t]{2}{*}{ Number years } & \multicolumn{5}{|c|}{ Number per Year } & \multirow[t]{2}{*}{ Number of records } \\
\hline & & 1975 & 1976 & 1977 & 1978 & 1979 & \\
\hline \multicolumn{8}{|c|}{ Northern India (N IND) } \\
\hline DJF & 4 & - & 28 & 144 & 59 & 143 & 374 \\
\hline MAM & 5 & 55 & 43 & 158 & 33 & 89 & 378 \\
\hline JJA & 4 & - & 239 & 268 & 110 & 20 & 637 \\
\hline SON & 3 & - & 22 & 75 & 152 & - & 249 \\
\hline Sum per year & & 55 & 332 & 645 & 354 & 252 & 1638 \\
\hline Fraction $(\%)$ & & 3.4 & 20.3 & 39.4 & 21.6 & 15.4 & \\
\hline \multicolumn{8}{|c|}{ Southern Japan (S JP) } \\
\hline DJF & 4 & - & 10 & 15 & 165 & 104 & 294 \\
\hline MAM & 4 & 34 & 83 & - & 221 & 135 & 473 \\
\hline JJA & 4 & - & 50 & 61 & 610 & 93 & 814 \\
\hline SON & 3 & - & 189 & 80 & 360 & - & 629 \\
\hline Sum per year & & 34 & 332 & 156 & 1356 & 332 & 2210 \\
\hline Fraction $(\%)$ & & 1.5 & 15.0 & 7.1 & 61.4 & 15.0 & \\
\hline \multicolumn{8}{|c|}{ Southern India (S IND) } \\
\hline DJF & 3 & - & - & 207 & 6 & 13 & 226 \\
\hline MAM & 2 & - & - & 101 & - & 12 & 113 \\
\hline JJA & 3 & - & 148 & 178 & 5 & - & 331 \\
\hline SON & 2 & - & - & 136 & 7 & - & 143 \\
\hline Sum per year & & & 148 & 622 & 18 & 25 & 813 \\
\hline Fraction $(\%)$ & & & 18.2 & 76.5 & 2.2 & 3.1 & \\
\hline \multicolumn{8}{|c|}{ Subtropical Northeast Pacific (ST NEP) } \\
\hline DJF & 5 & 71 & 790 & 342 & 1317 & 850 & 3370 \\
\hline MAM & 5 & 392 & 728 & 728 & 1026 & 421 & 3295 \\
\hline JJA & 5 & 378 & 146 & 424 & 2654 & 72 & 3674 \\
\hline SON & 4 & 247 & 187 & 317 & 1160 & - & 1911 \\
\hline Sum per year & & 1088 & 1851 & 1811 & 6157 & 1343 & 12250 \\
\hline Fraction $(\%)$ & & 8.9 & 15.1 & 14.8 & 50.3 & 11.0 & \\
\hline \multicolumn{8}{|c|}{ South China (S CHINA) } \\
\hline DJF & 4 & - & 37 & 139 & 199 & 161 & 536 \\
\hline MAM & 5 & 106 & 122 & 89 & 128 & 227 & 672 \\
\hline JJA & 4 & - & 167 & 196 & 415 & 84 & 862 \\
\hline SON & 4 & - & 37 & 144 & 359 & - & 540 \\
\hline Sum per year & & 106 & 363 & 568 & 1101 & 472 & 2610 \\
\hline Fraction (\%) & & 4.1 & 13.9 & 21.8 & 42.2 & 18.1 & \\
\hline
\end{tabular}




\section{References}

Brunner, D., Staehelin, J., Jeker, D., and Wernli, H.: Nitrogen oxides and ozone in the tropopause region of the Northern Hemisphere: Measurements from commercial aircraft in 1995/1996 and 1997, J. Geophys. Res., 106, 27 673-27 699, 2001.

Butchart, N. and Remsberg, E. E.: The area of the stratospheric polar vortex as a diagnostic for tracer transport on an isentropic surface, J. Atmos. Sci., 43, 1319-1339, 1986.

De Laat, A. T. J.: On the origin of tropospheric $\mathrm{O}_{3}$ over the Indian Ocean during the winter monsoon: African biomass burning vs. stratosphere-troposphere exchange, Atmos. Chem. Phys., 2, 325-341, 2002,

http://www.atmos-chem-phys.net/2/325/2002/.

Dias-Lalcaca, P., Brunner, D., Imfeld, W., Moser, W., and Staehelin, J.: An Automated System for the Measurement of Nitrogen Oxides and Ozone Concentrations from a Passenger Aircraft: Instrumentation and First Results of the NOXAR Project, Environ. Sci. Technol., 32, 3228-3236, 1998.

DiNunno, B., Davis, D., Chen, G., Gregory, G., Sachse, G., Anderson, B., Vay, S., Avery, M., Ridley, B., Carroll, M., Walega, J., Montzka, D. Grahek, F., Bradshaw, J., Sandholm, S. Kondo, Y., Kok, G., Blake, D., Barrick, J., Fuelberg, H., Martin, B., and Balok, A.: Central/eastern North Pacific photochemical precursor distributions for fall/spring seasons as defined by airborne field studies, J. Geophys. Res., 108(D2), 8237, doi:10.1029/2001JD001044, 2003.

Falconer, P. D. and Holdeman, J. D.: Measurements of atmospheric ozone made from a GASP-equipped 747 airliner Mid-March, 1975, Geophys. Res. Lett., 3, 101-104, 1976.

Falconer, P. D., Pratt, R. W., and Mohnen, V. A.: The transport of atmospheric ozone and its measurements from aircraft and the Earth's surface, ASRC Publ. 656, Dep. of Transp., Fed. Aviat. Admin., Washington, D.C., 109-147, 1978.

Falconer, P. D. and Pratt, R. .: A summary of research on the NASA-Global Atmospheric sampling program performed by the atmospheric sciences research center, Rep. NASA CR-1569614, NASA Lewis Res. Cent., Cleveland, Ohio, 58 pp., June 1979.

Falconer, P. D., Pratt, R., Detwiler, A., Chen, C.-S., Hogan, A., Bernard, S., Krebschull, K., and Winters, W.: Aircraft Measurements of Trace Gases and Particles Near the Tropopause, Rep. NASA CR 3691, NASA Lewis Res. Cent., Cleveland, Ohio, June 1983.

Fiore, A. M., Jacob, D. J., Logan, J. A., and Yin, J. H.: Long-term trends in ground level ozone over the contiguous United States, 1980-1995, J. Geophys. Res., 103, 1471-1480, 1998.

Fishman, J., Wozniak, A. E., and Creilson, J. K.: Global distribution of tropospheric ozone from satellite measurements using the empirically corrected tropospheric ozone residual technique: Identification of the regional aspects of air pollution, Atmos. Chem. Phys., 3, 893-907, 2003, http://www.atmos-chem-phys.net/3/893/2003/.

Forster, P. M. de F. and Shine, K. P.: Radiative forcing and temperature trends from stratospheric ozone changes, J. Geophys. Res., 102, 10 841-10 855, 1997.

Gauntner, D. J., Holdeman, J. D., Briehl, D., and Humenik, F. M.: Description and review of global measurements of atmospheric species from GASP, NASA Tech. Memo., TM-73781, 18 pp., 1977.

Gregory, G. L., Westberg, D. J., Shipham, M. C., Blake, D. R.,
Newell, R. E., Fuelberg, H. E., Talbot, R. W., Heikes, B. G., Atlas, E. L., Sachse, G. W., Anderson, B. A., and Thornton, D. C.: Chemical characteristics of Pacific tropospheric air in the region of the Intertropical Convergence Zone and South Pacific Convergence Zone, J. Geophys. Res., 104, 5677-5696, 1999.

Grosjean, D.: Ambient PAN and PPN in southern California from 1960 to the SCOS97-NARSTO, Atmos. Env., 37, 221-238, 2003.

Hearn, A. G.: The Absorption of Ozone in the Ultra-violet and Visible Regions of the Spectrum, Proc. Phys. Soc., 78, 932-940, 1961.

Hegglin, M. I., Brunner, D., Peter, T., Hoor, P., Fischer, H., Staehelin, J., Krebsbach, M., Schiller, C., Parchatka, U., and Weers, U.: Measurements of $\mathrm{NO}, \mathrm{NO}_{y}, \mathrm{~N}_{2} \mathrm{O}$, and $\mathrm{O}_{3}$ during SPURT: implications for transport and chemistry in the lowermost stratosphere, Atmos. Chem. Phys., 6, 1331-1350, 2006, http://www.atmos-chem-phys.net/6/1331/2006/.

Holdeman, J. D., Dudzinski, T. J., Nyland, T. W., and Tiefermann, M. W.: NASA Global Atmospheric Sampling Program (GASP) data report for tape VL0009, NASA Tech. Memo., TM-79058, 35 pp., 1978.

Holdeman, J. D. and Nastrom, G. D.: Ozone Contamination in Aircraft Cabins: Results from GASP Data and Analyses, NASA Tech. Memo., TM-81671, 7 pp., 1981a.

Holdeman, J. D. and Nastrom, G. D.: Analysis of Atmospheric Ozone Levels at Commercial Airplane Cruise Altitudes in Winter and Spring 1976-77, NASA Tech. Paper 1807, FAA-EE-81-1, 15 pp., 1981 b.

IPCC (Intergovernmental Panel on Climate Change): Climate change 2001: The scientific basis, Contribution of Working Group 1 to the Third Assessment Report, edited by: Houghton, J. T., Cambridge University Press, Cambridge, United Kingdom and New York, NY, USA, 891 pp., 2001.

Johnson, J. E., Gammon, R. H., Larsen, J., Bates, T. S., Oltmans, S. J., and Farmer, J. C.: Ozone in the marine boundary layer over the Pacific and Indian Oceans: Latitudinal gradients and diurnal cycles, J. Geophys. Res., 95, 11 847-11 856, 1990.

Klausen, J., Zellweger, C., Buchmann, B., and Hofer, P.: Uncertainty and bias of surface ozone measurements at selected Global Atmosphere Watch sites, J. Geophys. Res., 108(D19), 4622, doi:10.1029/2003JD003710, 2003.

Kley, D.: Tropospheric Chemistry and Transport, Science, 276, 1043-1045, 1997.

Kley, D., Smit, H. G. J., Vömel, H., Grassl, H., Ramanathan, V., Crutzen, P. J., Williams, S., Meyerwerk, J., and Oltmans, S. J.: Tropospheric water-vapour and ozone cross-sections in a zonal plane over the central equatorial Pacific Ocean, Q. J. R. Meteor. Soc., 123, 2009-2040,1997.

Kulshreshta, U. C., Jain, M., and Parashar, D. C.: Concentrations and behavior of surface $\mathrm{O}_{3}, \mathrm{NO}$ and $\mathrm{NO}_{2}$ at Delhi, Indian J. Radio Space Phys., 26, 82-84, 1997.

Lange, R., Savage, M., and Peyton, B.: Design, Development, and Field Testing of Infrared Heterodyne Radiometer (IHR) for Remote Profiling of Tropospheric and Stratospheric Species, NASA Contractor Report, 3448, 1981.

Liu, S. C., McFarland, M., Kley, D., Zafiriou, O., and Huebert, B.: Tropospheric $\mathrm{NO}_{\mathrm{x}}$ and $\mathrm{O}_{3}$ budgets in the equatorial Pacific, J. Geophys. Res., 88, 1360-1368, 1983.

Liu, H., Jacob, D. J., Chan, L. Y., Oltmans, S. J., Bey, I., Yantosca, R. M., Harris, J. M., Duncan, B. N., and Martin, R. V.: Sources 
of tropospheric ozone along the Asian Pacific Rim: An analysis of ozonesonde observations, J. Geophys. Res., 107(D21), 4573, doi:10.1029/2001JD002005, 2002.

Logan, J. A.: Tropospheric ozone: Seasonal behavior, trends and anthropogenic influence, J. Geophys. Res., 90, 10463-10 482, 1985.

Logan, J. A.: An analysis of ozonesonde data for the troposphere: Recommendation for testing 3-D models and development of a gridded climatology for tropospheric ozone, J. Geophys. Res., 104, 16 115-16 149, 1999.

Logan, J. A., Megretskaia, I. A., Miller, A. J., Tiao, G. C., Choi, D., Zhang, L., Stolarski, R. S., Labow, G. J., Hollandsworth, S. M., Bodeker, G. E., Claude, H., De Muer, D., Kerr, J. B., Tarasick, D. W., Oltmans, S. J., Johnson, B., Schmidlin, F., Staehelin, J., Viatte, P., and Uchino, O.: Trends in the vertical distribution of ozone: A comparison of two analyses of ozonesonde data, J. Geophys. Res., 104, 26373-26399, 1999.

Lu, R. and Turco, R. P.: Air pollution transport in a coastal environment: Part II: three-dimensional simulations over the Los Angeles basin, Atmos. Env., 29, 1499-1518, 1995.

Lu, R. and Turco, R. P.: Ozone distributions over the Los Angeles basin: Three-dimensional simulations with the SMOG model, Atmos. Env., 30, 4155-4176, 1996.

Marenco, A., Thouret, V., Nédélec, P., Smit, H., Helten, M., Kley, D., Karcher, F., Simon, P., Law, K., Pyle, J., Poschmann, G., Von Wrede, R., Hume, C., and Cook, T.: Measurement of ozone and water vapour by Airbus in-service aircraft: The MOZAIC program, An overview, J. Geophys. Res., 103, 25 631-25 642, 1998.

Naja, M. and Lal, S.: Changes in surface ozone amount and its diurnal and seasonal patterns, from 1954-55 to 1991-93, measured at Ahmedabad (23 N), India, Geophys. Res. Lett., 23, 81-84, 1996.

Naja, M. and Lal, S.: Surface ozone and precursor gases at Gadanki $\left(13.5^{\circ} \mathrm{N}, 79.2^{\circ} \mathrm{E}\right)$, a tropical rural site in India, J. Geophys. Res., 107(D14), 4197, doi:10.1029/2001JD000357, 2002.

Naja, M. and Akimoto, H.: Contribution of regional pollution and long-range transport to the Asia-Pacific region: Analysis of long-term ozonesonde data over Japan, J. Geophys. Res., 109, D21306, doi:10.1029/2004JD004687, 2004.

Nastrom, G. D.: Vertical and horizontal fluxes of ozone at the tropopause from the first year of GASP data, J. Appl. Meteor., 16, 740-744, 1977.

Nastrom, G. D.: Ozone in the upper troposphere from GASP measurements, J. Geophys. Res., 84, 6383-6388, 1979.

Newchurch, M. J., Ayoub, M. A., Oltmans, S., Johnson, B., and Schmidlin, F. J.: Vertical distribution of ozone at four sites in the United States, J. Geophys. Res., 108(D1), 4031, doi:10.1029/2002JD002059, 2003.

Oltmans, S. J., Hofmann, D. J., Lathrop, J. A., Harris, J. M., Komhyr, W. D., and Kuniyuki, D.: Tropospheric ozone during Mauna Loa Observatory Photochemistry Experiment 2 compared to long-term measurements from surface and ozonesonde observations, J. Geophys. Res., 101, 14 569-14 580, 1996.

Oltmans, S. J., Johnson, B. J., Harris, J. M., Vömel, H., Thompson, A. M., Koshy, K., Simon, P., Bendura, R. J., Logan, J. A., Hasebe, F., Shiotani, M., Kirchhoff, V. W. J. H., Maata, M., Sami, G., Samad, A., Tabuadravu, J., Enriquez, H., Agama, M., Cornejo, J., and Paredes, F.: Ozone in the Pacific tropical tro- posphere from ozonesonde observations, J. Geophys. Res., 106, 32 503-32 525, 2001.

Oltmans, S. J., Johnson, B. J., Harris, J. M., Thompson, A. M., Liu, H. Y., Chan, C. Y., Vömel, H., Fujimoto, T., Brackett, V. G., Chang, W. L., Chen, J.-P., Kim, J. H., Chan, L. Y., and Chang, H.-W.: Tropospheric ozone over the North Pacific from ozonesonde observations, J. Geophys. Res., 109, D15S01, doi:10.1029/2003JD003466, 2004.

Piotrowicz, S. R., Boran, D. A., and Fischer, C. J.: Ozone in the boundary layer of the equatorial Pacific Ocean, J. Geophys. Res., 91, $13113-13119,1986$.

Piotrowicz, S. R., Bezdek, H. F., Harvey, G. R., Springer-Young, M., and Hanson, K. J.: On the ozone minimum over the equatorial Pacific Ocean, J. Geophys. Res., 96, 18 679-18 687, 1991.

Perkins, P. J. and Reck, G. M.: Atmospheric constituent measurements using commercial 747 airliners, NASA Tech. Memo., TM X-71469, 7 pp., 1973.

Singh, H. B., Herlth, D., Kolyer, R., Salas, L., Bradshaw, J. D., Sandholm, S. T., Davis, J. Crawford, D. D., Kondo, Y., Koike, M., Talbot, R., Gregory, G. L., Sachse, G. W., Browell, E., Blake, D. R., Rowland, F. S., Newell, R., Merrill, J., Heikes, B., Liu, S. C., Crutzen, P. J., and Kanakidou, M.: Reactive nitrogen and ozone over the western Pacific: Distribution, partitioning, and sources, J. Geophys. Res., 101, 1793-1808, 1996.

Staehelin, J., Harris, N. R. P., Appenzeller, C., and Everhard, J.: Ozone trends: a review, Rev. Geophys., 39, 231-290, 2001.

Stohl, A., Wernli, H., James, P., Bourqui, M., Forster, C., Liniger, M. A., Seibert, P., and Sprenger, M.: A new perspective of stratosphere-troposphere exchange, B. Am. Meteorol. Soc., 84, 11, doi:10.1175/BAMS-84-11-565, 2003.

Thompson, A. M., Johnson, J. E., Torres, A. L., Bates, T. S., Kelly, K. C., Atlas, E., Greenberg, J. P., Ponahne, N. M., Yvon, S. A., Saltzman, E. S., Heikes, B. G., Mosher, B. W., Shashkov, A. A., and Yegorov, V. I.: Ozone observations and a model of marine boundary-layer photochemistry during SAGA 3, J. Geophys. Res., 98, 16 955-16968, 1993.

Thouret, V., Marenco, A., Nédélec, P., and Grouhel, C.: Ozone climatologies at 9-12 km altitude as seen by the MOZAIC airborne program between September 1994 and August 1996, J. Geophys. Res., 103, 25 653-25 679, 1998a.

Thouret, V., Marenco, A., Logan, J. A., Nédélec, P., and Grouhel, C.: Comparisons of ozone measurements from the MOZAIC airborne program and the ozone sounding network at eight locations, J. Geophys. Res., 103, 25 695-25 720, 1998 b.

Thouret, V., Cammas, J.-P., Sauvage, B., Athier, G., Zbinden, R., Nédélec, P., Simon, P., and Karcher, F.: Tropopause referenced ozone climatology and inter-annual variability (1994-2003) from the MOZAIC programme, Atmos. Chem. Phys., 6, 1033-1051, 2006, http://www.atmos-chem-phys.net/6/1033/2006/.

Tiefermann, M. W.: Ozone Measurement System for NASA Global Air Sampling Program, NASA Tech. Paper 1451, NASA Lewis Res. Cent., Cleveland, Ohio, 21 pp., May 1979.

Uppala, S. M., Kållberg, P. W., Simmons, A. J., Andrae, U., da Costa Bechtold, V., Fiorino, M., Gibson, J. K., Haseler, J., Hernandez, A., Kelly, G. A., Li, X., Onogi, K., Saarinen, S., Sokka, N., Allan, R. P., Andersson, E., Arpe, K., Balmaseda, M. A., Beljaars, A. C. M., van de Berg, L., Bidlot, J., Bormann, N., Caires, S., Chevallier, F., Dethof, A., Dragosavac, M., Fisher, 
M., Fuentes, M., Hagemann, S., Hólm, E., Hoskins, B. J., Isaksen, L., Janssen, P. A. E. M., Jenne, R., McNally, A. P., Mahfouf, J.-F., Morcrette, J.-J., Rayner, N. A., Saunders, R. W., Simon, P., Sterl, A., Trenberth, K. E., Untch, A., Vasiljevic, D., Viterbo, P., and Woollen, J.: The ERA-40 re-analysis, Q. J. Roy. Meteor. Soc., 131, 2961-3012, doi:10.1256/qj.04.176, 2005.

Van Aardenne, J. A., Dentener, F. J., Olivier, J. G. J., Klein Goldewijk, C. G. M., and Lelieveld, J.: A High Resolution Dataset of Historical Anthropogenic Trace Gas Emissions for the Period 1890-1990, Global Biogeochem. Cy., 15(4), 909-928, 2001.

Wang, Y., Jacob, D. J., and Logan, J. A.: Global simulation of tropospheric $\mathrm{O}_{3}-\mathrm{NO}_{\mathrm{x}}$-hydrocarbon chemistry. 3. Origin of tropospheric ozone and effects of nonmethane hydrocarbons, J. Geophys. Res., 103, 10757-10767, 1998.

Wang, P.-H., Cunnold, D. M., Trepte, C. R., Wang, H. J., Jing, P., Fishman, J., Brackett, V. G., Zawodney, J. M., and Bodeker, G. E.: Ozone variability in the midlatitude upper troposphere and lower stratosphere diagnosed from a monthly SAGE II climatology relative to the tropopause, J. Geophys. Res., 111, D21304, doi:10.1029/2005JD006108, 2006.

Wild, O., Sundet, J. K., Prather, M. J., Isaksen, I. S. A., Akimoto, J., Browell, E. V., and Oltmans, S. J.: Chemical transport model ozone simulations for spring 2001 over the western Pacific: Comparisons with TRACE-P lidar, ozonesondes, and Total Ozone Mapping Spectrometer columns, J. Geophys. Res., 108(D21), 8826, doi:10.1029/2002JD003283, 2003.

WMO: Assessment of Trends in the Vertical Distribution of ozone, SPARC Rep. 1, Global Ozone Research and Monitoring Project, Report No. 43, Geneva, Switzerland, 1998.

WMO: Scientific Assessment of ozone depletion: 1998. Global Ozone Research and Monitoring Project, Report No. 44, Geneva, Switzerland, 1999.
WMO: Scientific Assessment of ozone depletion: 2006. Global Ozone Research and Monitoring Project, Report No. 50, Geneva, Switzerland, 2007.

Wozniak, A. G.: Exploratory Analysis of Global Atmospheric Sampling Program Data, Master Thesis, South Dakota School of Mines and Technology, Rapid City, South Dakota, 173 pp., 1997.

Zachariasse, M., van Velthoven, P. F. J., Smit, H. G. J., Lelieveld, J., Mandal, T. K., and Kelder, H.: Influence of stratospheretroposphere exchange on tropospheric ozone over the tropical Indian Ocean during the winter monsoon, J. Geophys. Res., 105, 15 403-15 416, 2000.

Zachariasse, M., Smit, H. G. J., van Velthoven, P. F. J., and Kelder, H.: Cross-tropopause and interhemispheric transports into the tropical free troposphere over the Indian Ocean, J. Geophys. Res., 106, 28 441-28 452, 2001.

Zahn, A., Neubert, R., Maiss, M., and Platt, U.: Fate of long-lived trace species near the Northern Hemispheric tropopause: Carbon dioxide, methane, ozone, and sulfur hexafluoride, J. Geophys. Res., 104, 13 923-13 942, 1999.

Zhang, M., Uno, I., Carmichael, G. R., Akimoto, H., Wang, Z., Tang, Y., Woo, J.-H., Streets, D. G., Sachse, G. W., Avery, M. A., Weber, R. J., and Talbot, R. W.: Large-scale structure of trace gas and aerosol distributions over the western Pacific Ocean during the Transport and Chemical Evolution Over the Pacific (TRACE-P) experiment, J. Geophys. Res., 108(D21), 8820, doi:10.1029/2002JD002946, 2003. 